\title{
A 28-kyr Continuous Lacustrine Paleoseismic Record of the Intraplate, Slow-Slipping Fuyun Fault in Northwest China
}

\begin{abstract}
Jiawei Fan ${ }^{1,2,3 \star}$, Hongyan $\mathrm{Xu}^{1}$, Wei Shi ${ }^{1}$, Qiaoqiao Guo ${ }^{1}$, Siqi Zhang ${ }^{1}$, Xiaotong Wei ${ }^{1}$, Minggang $\mathrm{Cai}^{1}$, Shuaitang Huang ${ }^{4}$, Jiangyong Wang $^{5}$ and Jule Xiao ${ }^{6,7,8}$

${ }^{1}$ State Key Laboratory of Earthquake Dynamics, Institute of Geology, China Earthquake Administration, Beijing, China, ${ }^{2} X i n j i a n g$ Pamir Intracontinental Subduction National Field Observation and Research Station, Beijing, China, ${ }^{3}$ Urumqi Institute of Central Asia Earthquake, China Earthquake Administration, Urumqi, China, ${ }^{4}$ Earthquake Agency of Xinjiang Uygur Autonomous Region, Urumqi, China, ${ }^{5}$ College of Urban and Environmental Science, Northeast Normal University, Changchun, China, ${ }^{6}$ CAS Key Laboratory of Cenozoic Geology and Environment, Institute of Geology and Geophysics, Chinese Academy of Sciences, Beijing, China, ${ }^{7}$ CAS Center for Excellence in Life and Paleoenvironment, Beijing, China, ${ }^{8}$ College of Earth and Planetary Sciences, University of Chinese Academy of Sciences, Beijing, China
\end{abstract}

OPEN ACCESS

Edited by:

Chong $X u$,

Ministry of Emergency Management,

China

Reviewed by:

Qi Yao,

China Earthquake Administration,

China

Xiangli $\mathrm{He}$

China Earthquake Administration,

China

*Correspondence:

Jiawei Fan

jwfan@ies.ac.cn

Specialty section: This article was submitted to

Geohazards and Georisks,

a section of the journal

Frontiers in Earth Science

Received: 04 December 2021 Accepted: 10 January 2022

Published: 27 January 2022

Citation:

Fan J, Xu H, Shi W, Guo Q, Zhang S, Wei $X$, Cai $M$, Huang $S$, Wang $J$ and Xiao J (2022) A 28-kyr Continuous Lacustrine Paleoseismic Record of the Intraplate, Slow-Slipping Fuyun Fault in Northwest China.

Front. Earth Sci. 10:828801. doi: 10.3389/feart.2022.828801
The Fuyun Fault is a typical intraplate, slow-slipping fault, but has been repeatedly ruptured by surface wave magnitude $\left(M_{s}\right) \geq 8.0$ earthquakes. The 11 August $1931 M_{s} 8.0$ Fuyun earthquake resulted in more than 10,000 casualties in the sparsely populated Fuyun area. Cosmogenic ${ }^{10} \mathrm{Be}$ dating of offset landforms produced by prehistoric $M_{s} \geq 8.0$ earthquakes yields an average recurrence interval of 9,700 $\pm 3,300$ years, much longer than previously estimated 2,000-4,500 years, clouding our understanding of the timing and recurrence behavior of past earthquakes originating from the Fuyun Fault. Reflection seismic data reveal widely distributed subaquatic faults in Yileimu Lake, implying high sensitivity of the lake sediments to paleoearthquakes originating from the Fuyun Fault. Two new long sediment cores (Y20A: $267 \mathrm{~cm}$; Y20B: $890 \mathrm{~cm}$ ) together with previously published two short cores (Y19: $71 \mathrm{~cm}$; Y20: $31.5 \mathrm{~cm})$ from the depocenter and nearshore zone of Yileimu Lake are used for stratigraphic correlations and analyses of sedimentary structures, grain-size distributions, magnetic susceptibility, elemental composition and carbon content. The mass-wasting deposits with underlying softsediment deformation structures (SSDS) in the Y20B core indicate six siliciclasticenriched sandy sediment fluxes from earthquake-triggered landslides of granitic rocks, and isolated SSDS record three additional earthquake-induced in situ deformations. Turbidite-like deposits with sorting indices $>3$ and $\mathrm{Si}$ contents $>700$ counts per second (cps) are comparable to those of the seismic mass-wasting deposits, and are thus interpreted as seismites from earthquake-induced re-deposition of nearshore sediments. There are a total of 20 seismic events recorded by the Y20B core. Seismic intensity calculation results, combined with historical seismic data, provide potential magnitudes of $M_{s} \geq 8.0, M_{s} \geq 7.0$, and $M_{s} \geq 5.5$ for the earthquake-triggered masswasting deposits, SSDS, and turbidite-like seismites, respectively, in Yileimu Lake, generally consistent with previously published magnitude thresholds. Radiocarbon dating and stratigraphic correlations constrain the timing of these past earthquakes to 
$\sim 28 \mathrm{cal}$ kyr BP. This unique, long lacustrine paleoseismic record suggests a weakly periodic pattern with recurrence intervals between 2,317 and 7,830years and an average of 5,303 years for potential $M_{s} \geq 8.0$ earthquakes, and reveals an unprecedented high frequency of potential $M_{s} \geq 7.0$ earthquakes originating from the Fuyun Fault in the last $5 \mathrm{kyr}$, demonstrating the urgent need for an improved assessment of seismic hazards and risks in the Fuyun Fault zone.

Keywords: mass-wasting deposits, soft-sediment deformations, turbidite, shaking intensity, recurrence behavior, intraplate fault

\section{INTRODUCTION}

In recent decades, the frequent occurrence of catastrophic earthquakes (e.g., the 17 August $1999 M_{s} 7.4$ earthquake in Turkey, the 8 October $2005 M_{s} 7.6$ earthquake in Pakistan, and the 12 May $2008 M_{s} 8.0$ earthquake in China) produced by sudden stress release of intraplate active faults have resulted in massive casualties, property loss and ecological destruction (Vanholder et al., 2001; Sullivan and Hossain, 2010; Cui et al., 2012). The Fuyun Fault is a typical intraplate fault located at the junction of Tianshan-Altay and Mongolia-Baikal seismic zones, an area with frequent large earthquakes (Pollitz et al., 2003). A rupture along the $\sim 170-\mathrm{km}$ long Fuyun Fault produced the 11 August $1931 M_{s}$ 8.0 Fuyun earthquake with a maximum horizontal coseismic displacement of $\sim 14 \mathrm{~m}$. It resulted in more than 10,000 casualties, causing great trauma to the sparsely populated Fuyun area (Fuyun County Local Chronicles Compilation Committee, 2003). The Fuyun Fault is a slowslipping fault but evidence indicates that it ruptured repeatedly generating prehistoric $M_{s} \geq 8.0$ earthquakes (Klinger et al., 2011; Xu et al., 2012). Mapping of the Fuyun Fault offsets using satellite and geomorphological data and cosmogenic ${ }^{10} \mathrm{Be}$ dating of the offset landforms yielded an average recurrence interval of $9,700 \pm 3,300$ years for the prehistoric earthquakes (Xu et al., 2012). However, such a long recurrence interval is in sharp contrast with the previously estimated interval of 2,000-4,500 years in Xinjiang active tectonic zones ( $\mathrm{Xu}$ and Deng, 1996).

The short instrumental and historical earthquake records in the Fuyun area is insufficient to determine the long-term recurrence behavior of devastating earthquakes from such intraplate faults (Avşar et al., 2014; Howarth et al., 2014; Moernaut, 2020). Quaternary deposits in the Altay region are sporadic, limiting the investigation of paleoseismic trenches for the Fuyun Fault. Dendroseismological studies can provide absolute ages for past earthquakes associated with the Fuyun Fault (Lin and Lin, 1998). However, seismic intensity thresholds for tree-ring responses are poorly constrained in the fault area due to the scarcity of historical earthquake events (e.g., Fan et al., 2020a), and dendrochronological studies may be limited to a much shorter time span than the long return periods of multiple great earthquakes. Therefore, paleoseismic records with a long time span and containing information regarding earthquake size are urgently needed to gain a better understanding of seismic activities on the Fuyun Fault.
Continuously deposited lake sediments in fault-bounded basins potentially contain detailed information on the occurrence and age of paleoearthquake events (e.g., Strasser et al., 2006; Berryman et al., 2012; Hubert-Ferrari et al., 2020; Kremer et al., 2020; Moernaut, 2020; Oswald et al., 2021). Previous lacustrine paleoseismic studies have provided some intensity thresholds for earthquake-induced sedimentary and deformation processes: a Modified Mercalli Intensity (MMI) of 5-6 induced turbidite deposition in Rara Lake, western Nepal (Ghazoui et al., 2019); an intensity of 6-7 MMI produced soft-sediment deformation structures (SSDS) in Lungerer Lake, Seelisberg Lake and Baldegger Lake, central Switzerland (Monecke et al., 2004); and a violent shaking intensity of 9 MMI caused extensive landslides and triggered mass-wasting deposits in Mapourika Lake, Paringa Lake and Ellery Lake, New Zealand (Howarth et al., 2016). The intensity thresholds for earthquake-induced lacustrine sedimentary events provide a means to investigate the location and magnitude of past earthquakes and to determine the recurrence pattern of earthquake events of different intensities (Moernaut et al., 2018; Lu et al., 2020).

Yileimu Lake is bounded by the Fuyun Fault (Figure 1A), making this site particularly sensitive to seismic activities originating from the fault. A recent study based on a $71-\mathrm{cm}$ long sediment core from Yileimu Lake provided a 450-years continuous paleoseismic record related to the Fuyun Fault (Fan et al., 2020b). Here, we present an extended history of this paleoseismic record to $\sim 28$ cal kyr BP, through high-resolution analyses of chronology and sedimentary events including mass-wasting deposits, SSDS and turbidite-like deposits in an $890-\mathrm{cm}$ long sediment core from Yileimu Lake, and through careful statistical analysis of grain-size data, and elemental composition. The sedimentary events in this unique, long paleoseismic record are constrained by different shaking intensities, providing an in-depth understanding of the magnitude, frequency and recurrence behavior of past earthquakes on the Fuyun Fault since $28 \mathrm{cal}$ kyr BP.

\section{MATERIALS AND METHODS}

\section{Study Area}

The Fuyun Fault is a $170-\mathrm{km}$ long intraplate strike-slip fault in southern Altay, northern Xinjiang, which is on the border of China, Mongolia and Russia (Figure 1A). It consists of two segments: one is a $\sim 50 \mathrm{~km}$-long normal fault, constituting the northern segment; the other is a $\sim 120 \mathrm{~km}$-long right-lateral slip 


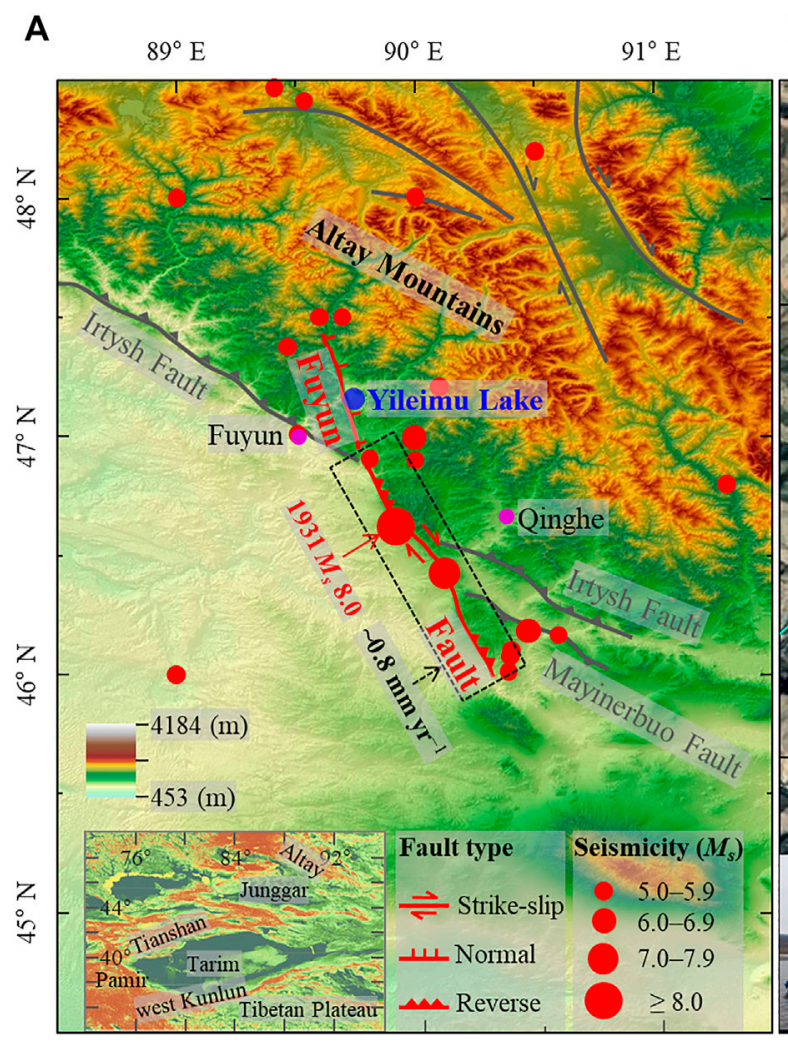

B

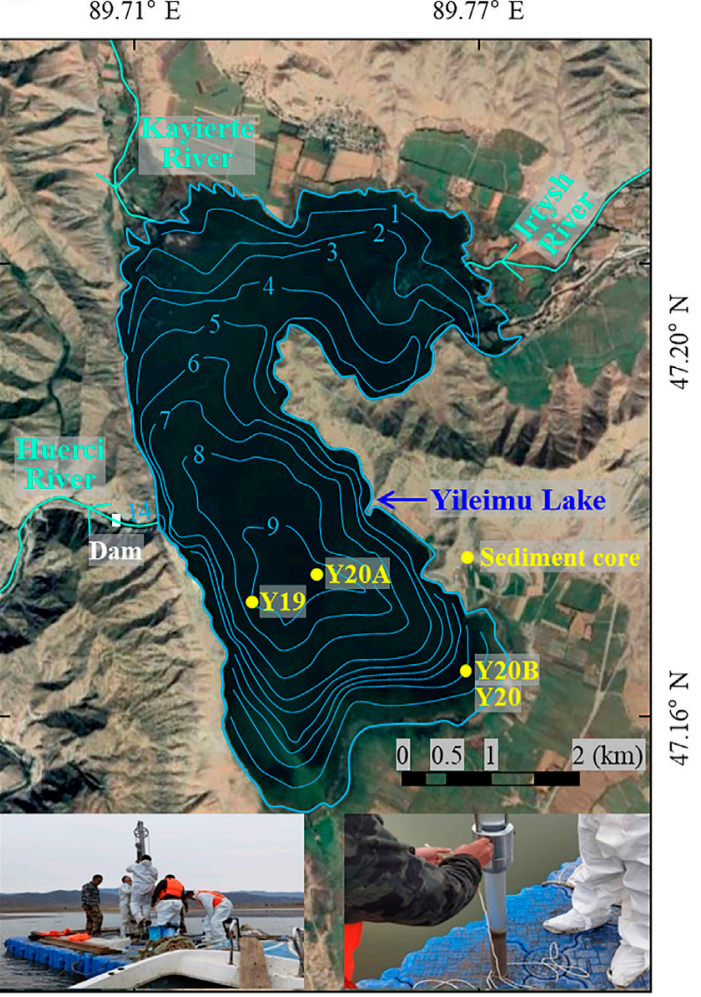

FIGURE 1 | (A) Locations and characteristics of the Fuyun Fault, Yileimu Lake, and historical earthquakes around the fault. The average strike-slip rate was $~ 0.8$ mm year $^{-1}$ in the late Pleistocene (Bai et al., 1996; Xu et al., 2012). Fault and earthquake data were first published by Fan et al. (2020b). Digital Elevation Model (DEM) is from http:// www.gscloud.cn/. (B) Bathymetric map of Yileimu Lake, and locations of sediment cores. Bathymetric data are from Fan et al. (2020b). Inset images show the sediment coring.

fault with a thrust component, constituting the southern segment (Figure 1A) (Ding, 1985; Klinger et al., 2011; Xu et al., 2012). The southern segment of the fault is more active, in response to the southeastward movement of the Mongolia and Siberia blocks and to the far-field effect of India-Eurasia collision (Shen et al., 2003). The average strike-slip rate was $\sim 0.8 \mathrm{~mm} \mathrm{year}^{-1}$ in the late Pleistocene (Bai et al., 1996; Xu et al., 2012). Historical earthquake records cover only 120 years, but document an $M_{s}$ 8.0 earthquake that ruptured the whole Fuyun Fault and triggered extensive landslides in 1931 AD (Figure 1A) (Fuyun County Local Chronicles Compilation Committee, 2003).

Yileimu Lake is a permanent lake formed by depression of the northern segment of the Fuyun Fault (Klinger et al., 2011). It is fed by the Kayierte and Irtysh Rivers and is discharged by the Huerci River (Figure 1B). The current lake level is mainly controlled by an artificial dam (20.8 $\mathrm{m}$ above the ground) located $\sim 0.5 \mathrm{~km}$ downstream along the Huerci River (Figure 1B). The dam was built in 1958-1967 AD (Fuyun County Local Chronicles Compilation Committee, 2003). Yileimu Lake has a maximum water depth of $\sim 9 \mathrm{~m}$ in the depocenter, and the lake floor is flat in the north and relatively steep in the south (Figure 1B) (Fan et al., 2021). Hills of granitic rocks with an average slope of $\sim 35^{\circ}$ occur along the Fuyun Fault, bounding the western margin of the lake (Figures 1A,B, Supplementary Figure S1A). The lake is surrounded by lacustrine plains along the northern, northeastern, southeastern and southern shores (Figure 1B). The catchment area has $\sim 300 \mathrm{~m}$ of relief between the mountain peaks and lake surface, and landslides appear on the slopes to the southwest of the lake. Chemical weathering is relatively weak in the Altay Mountains, limiting the sediment sources for the lake to some extent (Fan et al., 2021).

\section{Reflection Seismic Survey and Sediment Coring}

A reflection seismic survey was conducted along nine seismic lines across Yileimu Lake in May 2021 (only three lines A, B and C in Supplementary Figure S1A have relatively clear seismic reflectors). Reflection seismic data were acquired using an Applied Acoustics Engineering (AAE) CSP-D2400 system in combination with a GeoAcoustics 5210A system. A Receiver Model 5210A was used to collect seismic data from an AA301 boomer seismic sound source $(200 \mathrm{~J})$ and a 20 -unit hydrophone $(100-4,000 \mathrm{~Hz})$, and to collect differential Global Positioning System (DGPS) data. A band-pass filter of 200-15,000 Hz was applied and seismic data interpretation was performed using SonarWiz 7 (v7.07.04) software.

In September 2020, a 267-cm long sediment core (Y20A; $47.176^{\circ} \mathrm{N}, 89.740^{\circ} \mathrm{E}$ ) and an $890-\mathrm{cm}$ long sediment core (Y20B; $47.165^{\circ} \mathrm{N}, 89.764^{\circ} \mathrm{E}$ ) were retrieved from the depocenter (at a 
TABLE 1 | Accelerator Mass Spectrometry (AMS) ${ }^{14} \mathrm{C}$ ages for the Y2OA and Y20B cores.

\begin{tabular}{|c|c|c|c|c|c|c|}
\hline Laboratory number & $\begin{array}{l}\text { Depth } \\
\text { (cm) }\end{array}$ & Dating material & $\begin{array}{l}\delta^{13} C \\
(\% \circ)\end{array}$ & $\begin{array}{c}\text { Conventional }{ }^{14} \mathrm{C} \text { age } \\
\text { (year BP) }\end{array}$ & $\begin{array}{c}\text { Corrected }{ }^{14} \mathrm{C} \text { age }^{\mathrm{a}} \\
\text { (year BP) }\end{array}$ & $\begin{array}{c}\text { Calibrated }{ }^{14} \mathrm{C} \text { age }(2 \sigma) \\
\text { (cal year BP) }\end{array}$ \\
\hline NENUR11114 $4^{\mathrm{b}}$ & Core top ${ }^{c}$ & Organic matter & -19.1 & $890 \pm 30$ & & $-70^{\mathrm{d}}$ \\
\hline NENUR11115 & $45^{\mathrm{c}}$ & Organic matter & -14.3 & $8,800 \pm 60^{e}$ & $3,070 \pm 70$ & $3,125-3,496$ \\
\hline Beta-597772 ${ }^{f}$ & $50^{c}$ & Organic matter & -21.1 & $8,820 \pm 30^{e}$ & $3,090 \pm 35$ & $3,261-3,435$ \\
\hline NENUR11118 & $200^{c}$ & Organic matter & -18.2 & $13,600 \pm 100^{\mathrm{e}}$ & $7,870 \pm 105$ & $8,504-9,046$ \\
\hline NENUR11120 & $375^{c}$ & Organic matter & -17.7 & $16,460 \pm 150^{e}$ & $10,730 \pm 155$ & $12,224-13,135$ \\
\hline Beta-597774 $4^{f}$ & $450^{c}$ & Organic matter & -19.9 & $24,270 \pm 80$ & & \\
\hline Beta-558775 ${ }^{f}$ & $650^{c}$ & Organic matter & -20.8 & $20,110 \pm 60^{e}$ & $14,380 \pm 70$ & $17,377-17,885$ \\
\hline Beta-558776 ${ }^{f}$ & $850^{c}$ & Organic matter & -20.7 & $15,340 \pm 50$ & & \\
\hline NENUR11111 ${ }^{\mathrm{b}}$ & $198^{\mathrm{g}}$ & Branch & -21.5 & $3,090 \pm 35^{e}$ & $3,090 \pm 35$ & $3,261-3,435$ \\
\hline NENUR11113 $3^{\mathrm{b}}$ & $264^{g}$ & Wood & -23.6 & $3,180 \pm 35^{\mathrm{e}}$ & $3,180 \pm 35$ & $3,327-3,511$ \\
\hline
\end{tabular}

water depth of $9.21 \mathrm{~m}$ ) and nearshore zone (at a water depth of $2.00 \mathrm{~m}$ ) of Yileimu Lake, respectively (Figure 1B), using a Wink S5 sonic drill system (Canada). The sediment cores had a diameter of $55 \mathrm{~mm}$. The nearest offshore distances of the Y20A and Y20B cores were $\sim 1.2$ and $\sim 0.4 \mathrm{~km}$, respectively (Figure 1B). The Y20A and Y20B cores were split for X-ray fluorescence scanning, and then sampled at $0.5-\mathrm{cm}$ intervals for physical and chemical analyses. In addition, a 31.5-cm long sediment core (Y20) was retrieved near the $\mathrm{Y} 20 \mathrm{~B}$ core, and a $71-\mathrm{cm}$ long sediment core $\left(\mathrm{Y} 19 ; 47.175^{\circ} \mathrm{N}\right.$, $89.729^{\circ} \mathrm{E}$ ) was retrieved from the depocenter of the lake (Figure 1B), using a UWITEC gravity corer (Austria). The lithology, chronology and grain-size data from the Y19 (which was named "Y19B" in the previous study of Fan et al. 2020b) and Y20 cores were published (Fan et al., 2021) and are used for stratigraphic correlations in this study.

\section{Accelerator Mass Spectrometry (AMS) Radiocarbon Dating}

A total of eight bulk samples from organic-rich horizons of the Y20B core, plus one branch sample at $223 \mathrm{~cm}$ depth and one wood sample at $264 \mathrm{~cm}$ depth within the Y20A core, were selected for AMS ${ }^{14} \mathrm{C}$ dating. This was carried out at the Guangzhou Institute of Geochemistry, Chinese Academy of Sciences and the Beta Analytic Testing Laboratory, United States (Table 1). Organic matter from bulk samples was extracted through an AAA pretreatment process (washing with acid, alkali and acid) (Brock et al., 2010). Conventional ${ }^{14} \mathrm{C}$ ages were calibrated using the OxCal 7.1 calibration program (Bronk Ramsey and Lee, 2013) with IntCal20 calibration data (Reimer et al., 2020). An age-depth profile was constructed using a Bayesian Accumulation Model (Blaauw and Christen, 2011).

\section{X-Ray Fluorescence (XRF) Scanning}

One half of each of the Y20A and Y20B cores was smoothed, and then scanned on an Itrax core scanner. Radiographic images were scanned at a resolution of $0.1 \mathrm{~cm}$, using an Rh tube at $60 \mathrm{kV}$ voltage and $35 \mathrm{~mA}$ current. Relative element intensities were obtained at $30 \mathrm{kV}$ voltage and $55 \mathrm{~mA}$ current with an exposure time of $3 \mathrm{~s}$ for every $0.5 \mathrm{~cm}$. Principal component analysis (PCA) was conducted on the standardized proxy data ( $\mathrm{Si}, \mathrm{K}, \mathrm{Ti}, \mathrm{Fe}, \mathrm{Zr}, \mathrm{Al}, \mathrm{Mn}, \mathrm{Ca}, \mathrm{Rb}, \mathrm{Sr}$ ) of the Y20B core, using the software SPSS (Fan et al., 2016), in order to discriminate different sedimentary facies associated with different sedimentary processes, based on their distinguishable compositional characteristics (Praet et al., 2020; Wils et al., 2021). The main factor values (PCA F1 and F2) for each sample were calculated following the method of Fan et al. (2016).

\section{Analyses of Grain-Size Distributions and Magnetic Susceptibility (SUS)}

A total of 534 samples from the Y20A core and 1780 samples from the $\mathrm{Y} 20 \mathrm{~B}$ core were used for grain-size distribution analysis, and the Y20B core was also used for analysis of magnetic susceptibility. Grainsize data were measured using a Malvern Mastersizer 3000 laser grain-size analyzer, and SUS data were measured using a Bartington MS2 susceptibility meter at the Institute of Geology, China Earthquake Administration, following the method of Fan et al. (2020b). The Mastersizer 3000 automatically outputs the volume percentage of 100 grain-size fractions. Sorting index of each grain-size distribution was calculated using the GRADISTAT program (Blott and Pye, 2001). SUS values were normalized by the sample weight.

\section{Analysis of Total Inorganic Carbon (TIC) Content}

The Y20B core was sampled at 5-cm intervals (178 samples) for analysis of TIC content, using an Elementar Rapid CS Cube analyzer at the Institute of Geology, China Earthquake Administration. Each sample was separated into two subsamples. One subsample was used for the measurement of total carbon (TC) content, and the other was pretreated with $1 \mathrm{M}$ 


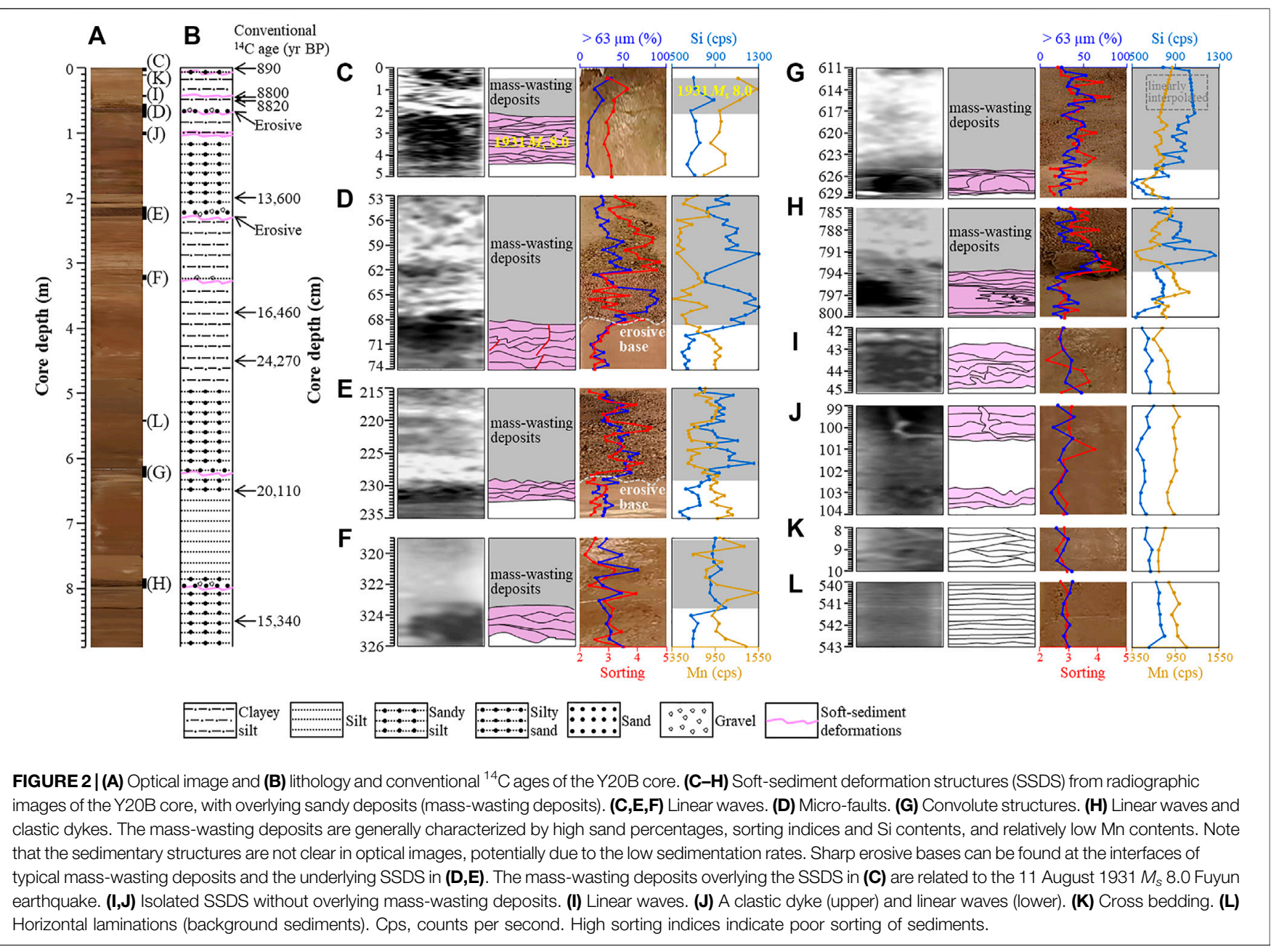

$\mathrm{HCl}$ to remove carbonates and then used for the measurement of total organic carbon (TOC) content, following the method of Fan et al. (2020b). TIC content was calculated as the difference between the TC and TOC contents.

\section{RESULTS}

\section{Seismic Stratigraphy and Core Lithology}

Seismic profiles from three lines across Yileimu Lake cover a maximum sediment depth of $\sim 15 \mathrm{~m}$ (Supplementary Figures S1A-D). The poor penetration of seismic reflection may be related to the presence of highly reflective sediments such as coarse gravels (Wils et al., 2021). Nevertheless, several subaquatic faults are clearly imaged by reflection offsets and changes in reflector characteristics in the same horizons (Supplementary Figures S1B-D). In contrast to subaquatic faults, river channels are characterized by a grooved shape without lithological differences of the same horizons (Supplementary Figure S1C).

The Y20B core is close to a subaquatic fault in the southeast of Yileimu Lake (Supplementary Figure S1B). It generally consists of a continuous lacustrine sequence. The sediments can be divided into six units (Figures 2A,B): $890-775 \mathrm{~cm}$, greyish-brown sandy silt with coarse sand and scattered gravel at $793.5-790 \mathrm{~cm}$; $775-650 \mathrm{~cm}$, brown silt; $650-495 \mathrm{~cm}$, brown sandy silt with silty sand at $624.5-611.5 \mathrm{~cm} ; 495-240 \mathrm{~cm}$, brown clayey silt with silt and scattered gravel at $323.5-319 \mathrm{~cm} ; 240-110 \mathrm{~cm}$, greyish-brown sandy silt with sand and scattered gravel at $228-215.5 \mathrm{~cm}$; $110-0 \mathrm{~cm}$, greyish-brown clayey silt with sand and scattered gravel at $68.5-53 \mathrm{~cm}$ and sandy silt at $2-0 \mathrm{~cm}$.

The Y20A core can be divided into two units (Supplementary Figure S2): $267-160 \mathrm{~cm}$, brownish-grey silty sand with coarse gravel and abundant plant residues at $267-260 \mathrm{~cm}$, plus coarse sand and scattered fine gravel at $260-254 \mathrm{~cm} ; 160-0 \mathrm{~cm}$, greenish-grey clayey silt with occasional black bands. The occurrence of coarse gravel at the bottom of the Y20A core hinders access to longer sediment cores in the depocenter of Yileimu Lake.

\section{AMS Radiocarbon Ages of Sediment Cores}

The conventional ${ }^{14} \mathrm{C}$ age of organic matter from the top of the Y20B core is $890 \pm 30$ years $\mathrm{BP}$, much older than the sampling date (Figure 2B; Table 1). The age data from the upper $450 \mathrm{~cm}$ of the Y20B core are generally consistent with stratigraphic order (Figure 2B; Table 1). The ${ }^{14} \mathrm{C}$ ages of organic matter at the depths of $45,50,200,375$ and $450 \mathrm{~cm}$ of the Y20B core are $8,800 \pm 60$, 


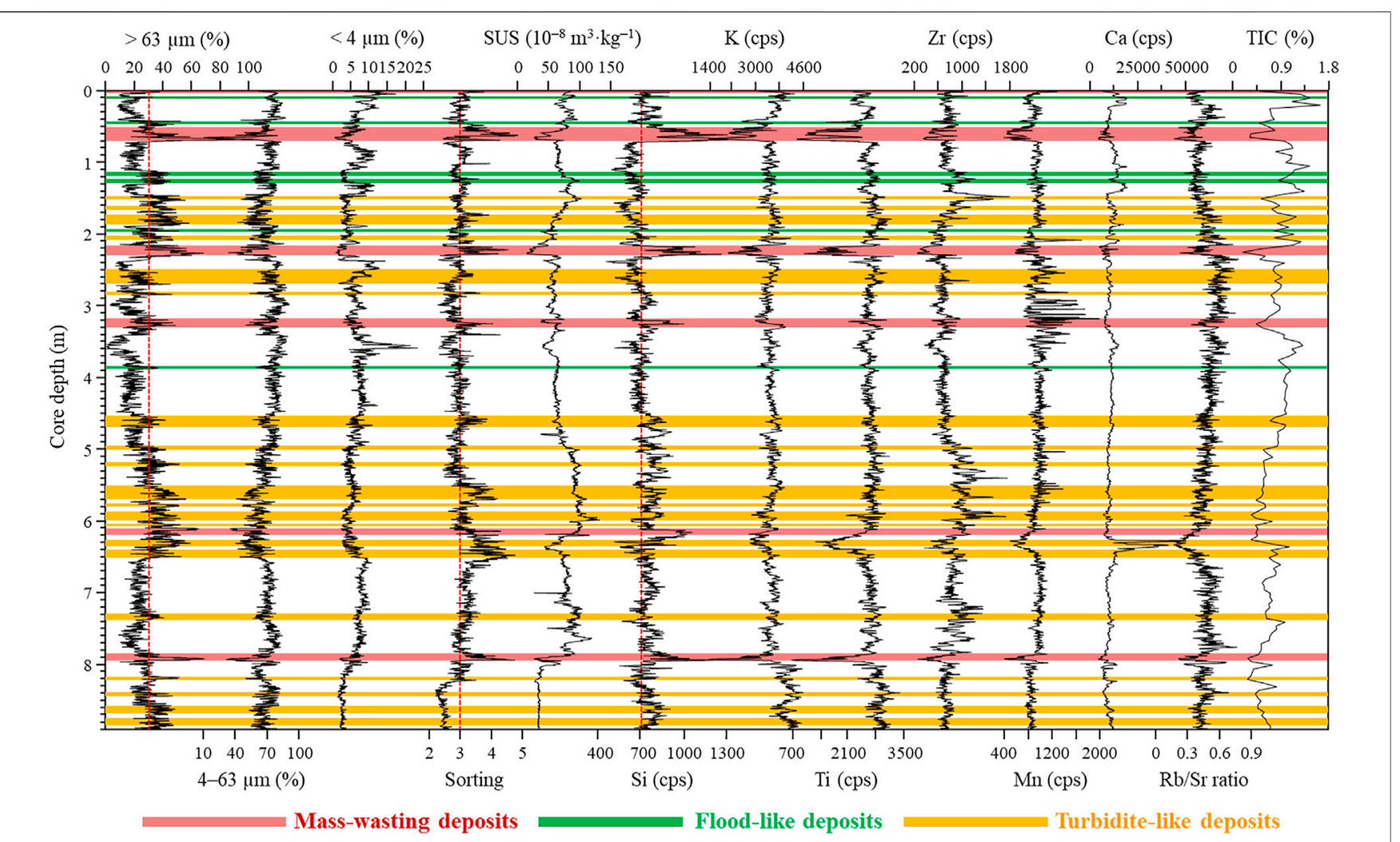

FIGURE 3 | Percentages of >63, 4-63 and <4 $\mu$ m fractions, sorting index, magnetic susceptibility (SUS), major elemental contents, Rb/Sr ratio and total inorganic carbon (TIC) of the Y20B core. Red, green and yellow bars indicate the horizons of mass-wasting deposits (corresponding to Figures $\mathbf{2 C - H}$ ), flood-like deposits and turbidite-like deposits, respectively. Flood-like deposits have cross bedding structures and turbidite-like deposits generally have normally graded bedding sequences.

$8,820 \pm 30,13,600 \pm 100,16,460 \pm 150$ and $24,270 \pm 80$ year BP respectively (Figure 2B; Table 1). Organic matter from the depth of $850 \mathrm{~cm}$ within the $\mathrm{Y} 20 \mathrm{~B}$ core has a ${ }^{14} \mathrm{C}$ age of $15,340 \pm 50$ years $\mathrm{BP}$, much younger than the age of 20,110 \pm 60 years BP found at $650 \mathrm{~cm}$ (Figure 2B; Table 1). The branch and wood from the depths of 198 and $264 \mathrm{~cm}$ of the Y20A core have conventional ${ }^{14} \mathrm{C}$ ages of $3,090 \pm 35$ and $3,180 \pm 35$ years $\mathrm{BP}$, respectively (Supplementary Figure S2; Table 1).

\section{Sedimentary Structures From XRF Radiographic Images}

Sedimentary structures are obtained from painstaking searches of radiographic and optical images at $0.1-\mathrm{cm}$ intervals throughout the Y20B and Y20A cores. The Y20B core contains 9 horizons of soft-sediment deformation structures (SSDS; Figures 2C-J), and six horizons of mass-wasting deposits overlying the SSDS (Figures $\mathbf{2 C}-\mathbf{H}$ ). The SSDS are $1-6.5 \mathrm{~cm}$ in thickness, and consist mainly of clayey silt (Figures $\mathbf{2 C}, \mathbf{I}, \mathbf{J}$ ) and sandy silt (Figures 2D-H). They include linear waves (Figures 2C,E,F,I,J), micro-faults (Figure 2D), a liquefied diaper or convolute structures (Figure 2G), linear waves and clastic dykes (Figure $\mathbf{2 H}$ ), and a clastic dyke (Figure 2J). The mass-wasting deposits are generally composed of poorly sorted medium- to coarse-sand with a massive structure and scattered gravel dispersed in (red bars in Figure 3). They are $2 \mathrm{~cm}$ (Figure 2C), $15.5 \mathrm{~cm}$ (Figure 2D), $14.5 \mathrm{~cm}$ (Figure 2E), $4 \mathrm{~cm}$ (Figure 2F), $13.5 \mathrm{~cm}$ (Figure 2G) and $8.5 \mathrm{~cm}$ (Figure 2H) in thickness, respectively. Except for the mass-wasting deposits at $624.5-611 \mathrm{~cm}$ depths, the others generally have normally graded sequences and clear lithological interfaces with the underlying SSDS (Figures 2C-H). There are no Bouma divisions, no horizontal or cross bedding, and no signs of bioturbation in the mass-wasting deposits. Sharp erosive bases can be found at the interfaces of typical mass-wasting deposits and the underlying SSDS (Figures 2D,E). The sediments consisting of sandy silt with clear crossbedding structures and normally graded bedding sequences in the Y20B core are regarded as flood-like deposits (Figure $\mathbf{2 K}$ ). The flood-like deposits are well sorted, and are less than $7 \mathrm{~cm}$ in thickness (green bars in Figure 3). In contrast, the sediments consisting of normally graded sandy silt without cross-bedding structures are regarded as turbidite-like deposits. The turbiditelike deposits have a wide range of thickness $(1-19.5 \mathrm{~cm}$ ) (yellow bars in Figure 3). The background sediments in the Y20B core mainly comprise laminated silt without graded sequences (e.g., Figure $2 \mathrm{~L}$ ). The Y20A core contains a horizon of mass-wasting deposits at $267-254 \mathrm{~cm}$ and a horizon of isolated SSDS layers (linear waves and convolute structures) at $171.7-168.2 \mathrm{~cm}$ (Supplementary Figure S2). 


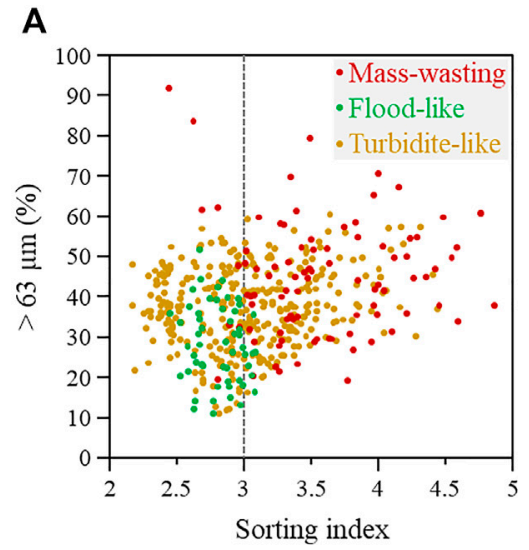

D

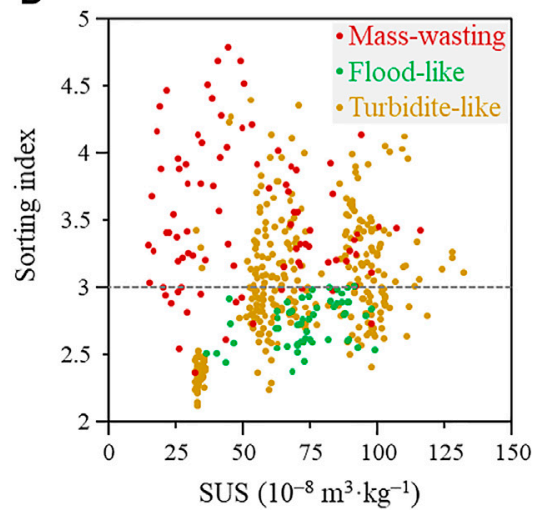

B

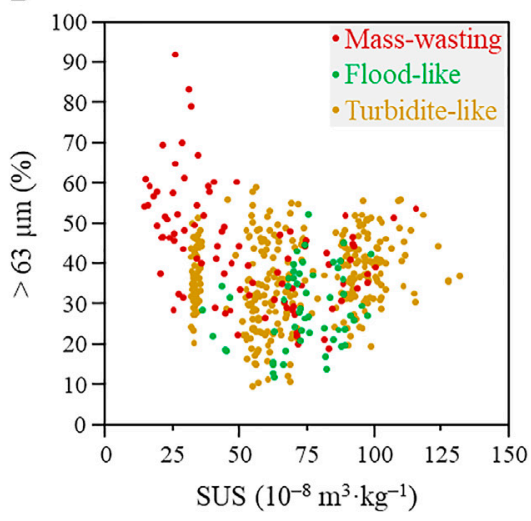

E

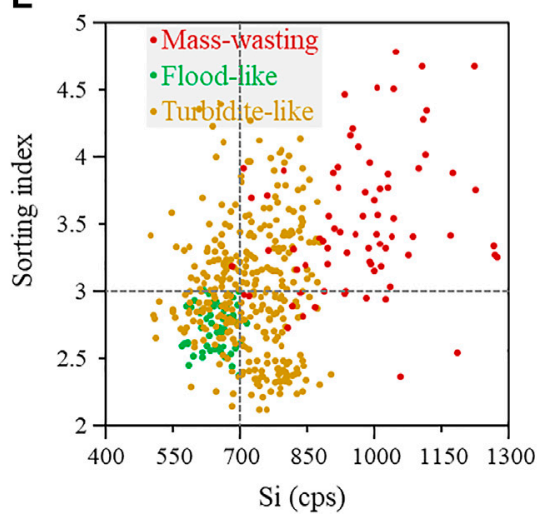

C

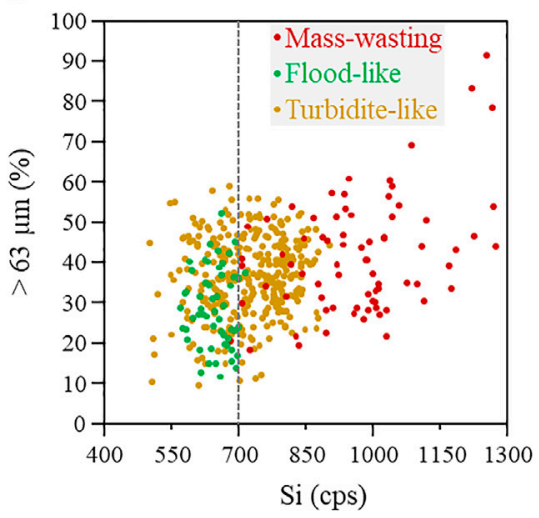

$\mathbf{F}$

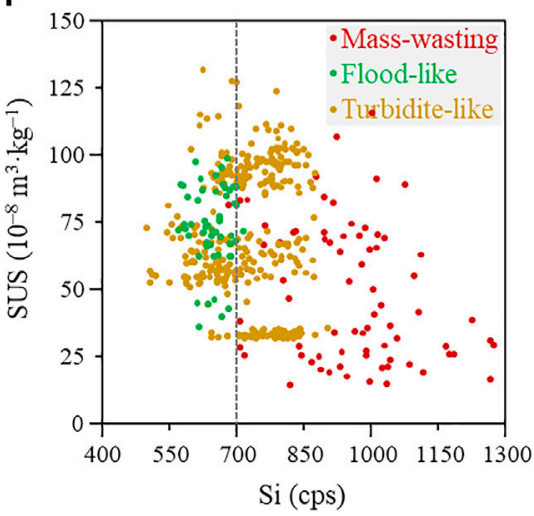

FIGURE 4 | Correlations between (A) percentage of $>63 \mu \mathrm{m}$ fraction and sorting index, (B) percentage of $>63 \mu \mathrm{m}$ fraction and SUS, (C) percentage of $>63 \mu \mathrm{m}$ fraction and Si content, (D) sorting index and SUS, (E) sorting index and Si content, and (F) SUS and Si content of the mass-wasting deposits, flood-like deposits and turbidite-like deposits from the Y20B core.

\section{Sedimentary Proxies}

There is no overall trend up the core in the variations of percentages of grain-size fractions, sorting index, SUS, major elemental contents or $\mathrm{Rb} / \mathrm{Sr}$ ratio of the Y20B core (Figure 3 ). The average percentages of $>63,4-63$ and $<4 \mu \mathrm{m}$ fractions are $24.7 \%, 69.3 \%$ and $6.0 \%$, respectively. Sorting index and SUS have average values of 2.9 and $66.9 \times 10^{-8} \mathrm{~m}^{3} \mathrm{~kg}^{-1}$, respectively. The average contents of $\mathrm{Si}, \mathrm{K}, \mathrm{Ti}, \mathrm{Zr}, \mathrm{Mn}$ and $\mathrm{Ca}$ are 721, 3,522, 2,617, 778, 940 and 10,696 counts per second (cps), respectively. $\mathrm{Rb} / \mathrm{Sr}$ ratios and TIC contents have averages of $0.46 \%$ and $0.77 \%$, respectively. There are a total of 32 horizons characterized by significantly high percentages of the $>63 \mu \mathrm{m}$ fraction (minimum peak value exceeds 30\%). Among them, six horizons (red bars in Figure 3) correspond to the mass-wasting deposits (Figures 2C-H) and six other horizons correspond to the flood-like deposits (green bars in Figure 3). The remaining 20 horizons are turbidite-like deposits (yellow bars in Figure 3), generally characterized by abrupt increases in the percentages of $>63 \mu \mathrm{m}$ fraction at the bottom and gradual decreases upwards. The masswasting deposits also have remarkably high sorting indices (generally higher than 3) (high sorting indices indicate poor sorting of sediments), low SUS values (minimum valley value is only $14 \times 10^{-8} \mathrm{~m}^{3} \mathrm{~kg}^{-1}$ ) and high Si contents (generally higher than $700 \mathrm{cps}$ with minimum peak value exceeding $890 \mathrm{cps}$ ) (Figures 2C-H, 3, 4). In addition, PCA F1 and F2 account for $43.4 \%$ and $19.8 \%$ of the total variance within the elemental dataset of the Y20B core, respectively (Figure 5A). Three clusters can be defined: the first is dominated by $\mathrm{Si}$, representing a quartz origin; the second is controlled by $\mathrm{Ca}$ and $\mathrm{Sr}$, reflecting a plagioclase and/ or carbonate origin; and the third is composed of $\mathrm{K}$ and other terrigenous elements ( $\mathrm{Ti}, \mathrm{Fe}, \mathrm{Rb}, \mathrm{Mn}, \mathrm{Al}$ and $\mathrm{Zr}$ ), with the $\mathrm{K}$ likely related to a $\mathrm{K}$-feldspar origin (Figure 5A). The mass-wasting deposits have PCA F2 values generally lower than zero, and possess the minimum values of both PCA F1 (-12) and F2 (-4.9) throughout the Y20B core (Figure 5B). In contrast, the flood-like deposits have relatively low sorting indices (generally lower than 3), low Si contents (generally lower than $700 \mathrm{cps}$ ), and relatively high PCA F2 values (generally higher than zero) (Figures $\mathbf{2 K}$, 3-5). The turbidite-like deposits have wide ranging sorting indices (2.1-4.1) and Si contents (497-868 cps) (Figures 3, 4), and have PCA F2 values generally lower than zero when their sorting index is higher than 3 (Figure 5B).

The Y20A core has ranges of mean grain size $(\mathrm{Mz})$, percentages of $>63 \mu \mathrm{m}$ fraction, and $\mathrm{Si}$ content from 9.1 to 

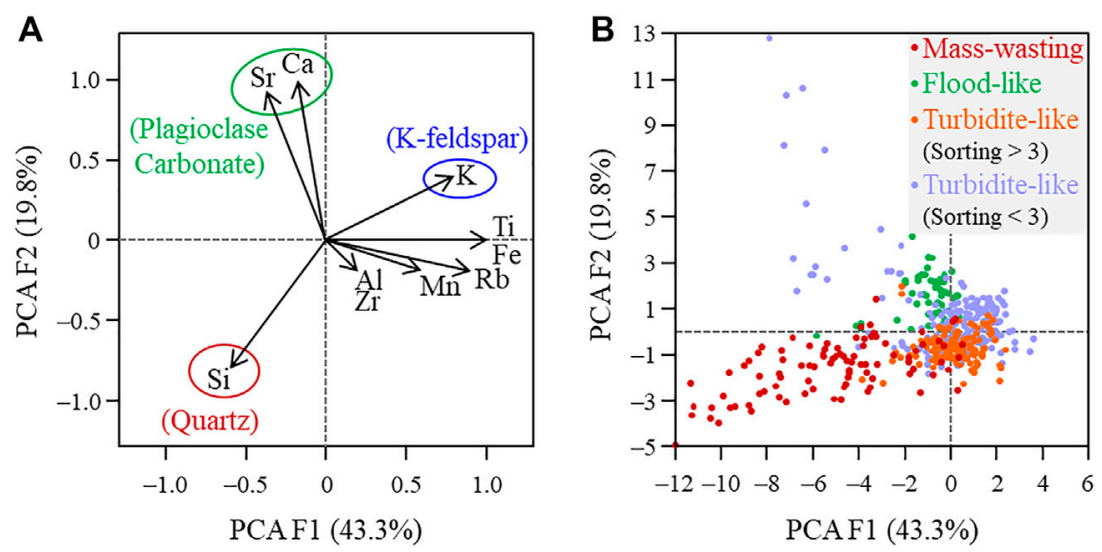

FIGURE 5 | (A) Variables factor map and (B) individuals factor map for principal component analysis (PCA) performed on the standardized elemental data of the Y20B core.

$321.4 \mu \mathrm{m}, \quad 0 \%-79.8 \%$, and $193-1376 \mathrm{cps}, \quad$ respectively (Supplementary Figure S3). The $260-158 \mathrm{~cm}$ depths of the Y20A core is characterized by relatively high values and decreasing trends of $\mathrm{Mz}$, percentages of $>63 \mu \mathrm{m}$ fraction and Si content, equivalent to the $70-40 \mathrm{~cm}$ depths of the Y20B core (orange bar in Supplementary Figure S3). The peak values of $\mathrm{Mz}$ and $\mathrm{Si}$ content at $254 \mathrm{~cm}$ within the Y20A core correspond to those at $65.5 \mathrm{~cm}$ within the Y20B core (Supplementary Figure S3). The radiocarbon sampling depths of 198 and $264 \mathrm{~cm}$ within the Y20A core can be cautiously correlated with the depths of 50 and $72 \mathrm{~cm}$ within the Y20B core, respectively (Supplementary Figure S3). The upper $2 \mathrm{~cm}$ of the Y20B core, the upper $5 \mathrm{~cm}$ of the Y19 core, and the upper $2.5 \mathrm{~cm}$ of the Y20 core can be confidently correlated with one other (Supplementary Figure S3). The age at $5 \mathrm{~cm}$ depth within the Y19 core is $1931 \mathrm{AD}$, corresponding to the 11 August $1931 M_{s} 8.0$ Fuyun earthquake (Fan et al., 2020b); therefore, the age at $2 \mathrm{~cm}$ depth within the Y20B core can also be inferred as 1931 AD (Supplementary Figure S3).

\section{DISCUSSION}

\section{Sedimentary Record of Paleoearthquakes}

Subaquatic faults are present in Yileimu Lake (Supplementary Figures S1A-D). These subaquatic faults should not be parts of the Fuyun Fault (Figure 1A, Supplementary Figure S1A). They were probably produced by seismic shaking from the Fuyun Fault, because the Fuyun Fault was the most active fault in the study area, and the lake was bounded by the Fuyun Fault (Figure 1A). The existence of these subaquatic faults suggests that the lake sediments are very sensitive to local seismic activities. However, there may be differences in the sedimentary response to seismicity in different areas of the lake. The Y20B core is located near a subaquatic fault in the nearshore zone of Yileimu Lake (Figure 1B, Supplementary Figure S1B), potentially representing a promising site to record past earthquakes. The Y20A core is located in the depocenter of Yileimu Lake (Figure 1B, Supplementary
Figure S1C), a location characterized by a flat lake floor and lack of coarse sediments.

Soft-sediment deformation structures (SSDS) in lake sediments (deformed sediments relative to the background sediments) can be triggered by co-seismic (Sims, 1973) and non-seismic processes such as gravity (Van Daele et al., 2014) and wave loading (Migeon et al., 2017). Yileimu Lake is bounded by the Fuyun Fault which produced at least 4 prehistoric $M_{s} \geq 8.0$ earthquakes (Klinger et al., 2011), and the SSDS consisting of linear waves, were related to the 11 August $1931 M_{s} 8.0$ Fuyun earthquake (Figure 2C) (Fan et al., 2020b). Some SSDS in the Y20B core contain high-angle micro-faults, a liquefied diaper or convolute structures, linear waves and clastic dykes, and a clastic dyke (Figures 2D,G,H,J), comparable to those produced by experimental and historical earthquakes (e.g., Jiang et al., 2016, 2017). Previous studies indicated that micro-faults were related to seismic-induced brittle failure of carbonate mud with a high initial lithification rate and a considerable strength and density shortly after deposition (Monecke et al., 2004 and references therein). The sedimentary layers of micro-faults at $74-68 \mathrm{~cm}$ depths of the Y20B core have much higher TIC (carbonate) contents than those of other types of SSDS (Figures 2C-J, 3). These micro-faults can be produced by an oscillatory movement of the water column and surface sediments during seismic shaking (Migeon et al., 2017). Changes in hydrodynamic conditions should have not been responsible for micro-faults, as evidenced by the absence of micro-faults in other layers of the Y20B core, and in lake sediments which experienced significant changes in hydrodynamic conditions and hardly affected by seismic activities in North China (e.g., Fan et al., 2019). Convolute structures were complex forms of load structures and interpreted as a combination of bulk-density heterogeneities and fluidization associated with water-escape structures during seismic shaking (Suter et al., 2011 and references therein). Linear waves were considered as the results of horizontal movement with different velocities of the laminated layers at water-sediment interfaces, associated with the occurrence of shear energy induced by earthquakes ( $\mathrm{Lu}$ et al., 2020; Wetzler et al., 2010). Clastic dykes were interpreted as the 


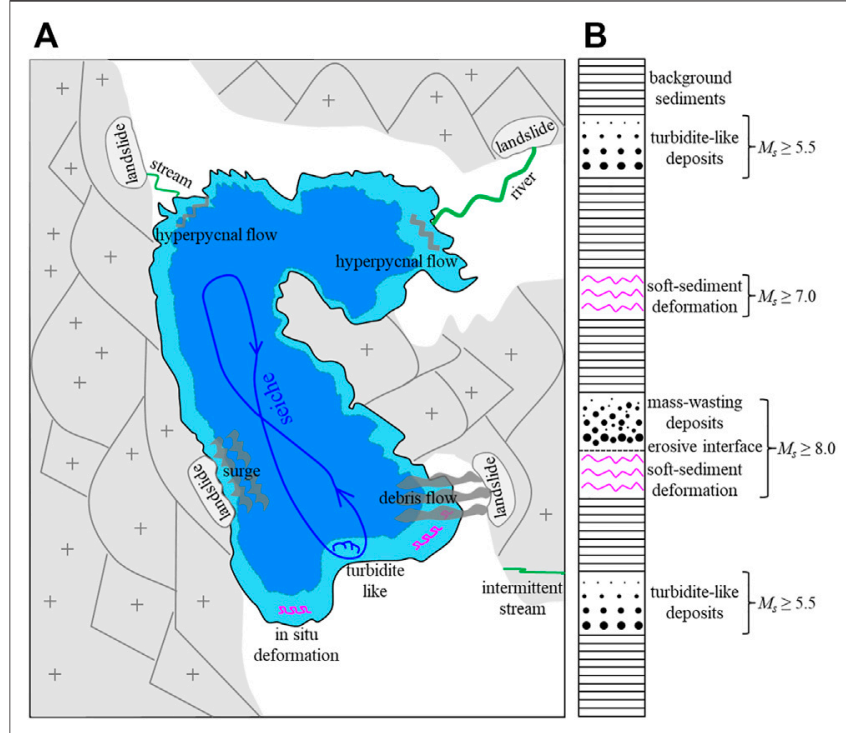

FIGURE 6 | A conceptual model showing (A) sedimentary processes in response to seismic shaking and $(\mathbf{B})$ earthquake imprints on a sediment core from the nearshore zone of the lake. Mass-wasting deposits include sediments transported by debris flows and hyperpycnal flows.

infillings of hydrofractures during the upward escape of seismicinduced fluidized sediments, when water pressures in the basal layer exceeded the overlying layer (Chen et al., 2009; Moretti, 2000). Therefore, the repeated occurrence of SSDS in the sediments of Yileimu Lake is most likely seismic origin (Figures 6A,B). The co-occurrence of some SSDS at the corresponding depths of the Y20A and Y20B cores (Supplementary Figures S2, S3) provides support for seismic origin of these widely distributed SSDS in Yileimu Lake. In contrast, gravity-induced SSDS should produce a dominant and regular direction of clastic materials (Van Daele et al., 2014), and wave loading-induced SSDS should produce parallel or regular cross bedding (Beck, 2009; Migeon et al., 2017). There are a total of 9 distinct horizons of SSDS in the Y20B core (Figures 2C-J), with each separated by non-seismic horizontal laminations (e.g., Figure 2J), indicating 9 past earthquakes originating from the Fuyun Fault (E1-E5, E7, E10, E15 and E19 in Figure 7).

Mass-wasting deposits in sediments from small lakes in tectonically active regions were interpreted as the products of coseismic landslides and/or subaqueous slope failures (e.g., Howarth et al., 2014; Lu et al., 2017; Van Daele et al., 2017). In order to distinguish landslide-related deposits from those subaqueous origins in Yileimu Lake, mass-wasting deposits are regarded only as post-seismic deposits from landslides in the lake catchment in this study. Mass-wasting deposits were commonly seen in sediments from small lakes in tectonically active regions (e.g., Howarth et al., 2014; Oswald et al., 2021). The 6 horizons of mass-wasting deposits in the Y20B core consist of poorly sorted sand and scattered, irregularly shaped gravel, and have no Bouma divisions or signs of bioturbation (Figures $\mathbf{2 C - H}, \mathbf{3}, 4$ ). The masswasting deposits in Yileimu Lake can be interpreted as post-seismic deposits transported by debris flows and/or hyperpycnal flows, reflecting coarse sediment fluxes from earthquake-triggered landslides from surrounding high and steep mountains (Figures 6A,B) (e.g., Howarth et al., 2012; Moernaut, 2020). The masswasting deposits overlying the SSDS in Yileimu Lake (Figures 2C-H) supports the seismic origin of landslides in the lake catchment and in situ deformations within the lake (e.g., Lu et al., 2021a). The sharp erosive bases at the interfaces of typical mass-wasting deposits and the underlying SSDS (Figures 2D,E) may have resulted from the horizontal movement of bottom water in the lake, induced by shear energy during seismic shaking. The mass-wasting deposits at the top of the Y20B core correspond to the 11 August $1931 M_{s} 8.0$ Fuyun earthquake (Figure 2C, Supplementary Figure S3). The thickness of these deposits is only $1.5 \mathrm{~cm}$, much thinner than the other 5 horizons of masswasting deposits (Figures 2C-H). Flood events in the 1900s AD may have expanded the size of the lake (Fan et al., 2021), possibly resulting in increasing distance between the site of the Y20B core and landslide sources, and thereby reducing the sediment flux to the core site. Increased water storage in Yileimu Lake after reservoir construction in the 1950s AD (Fan et al., 2020b) may have also reduced the sedimentation rate in the lake. These factors may therefore have reduced the thickness of the mass-wasting deposits related to the 11 August $1931 M_{s} 8.0$ Fuyun earthquake. The floodlike deposits are well sorted and have clear cross-bedding structures (e.g., Figures 2K, 3, 4), similar to those flood deposits formed in strong hydrodynamic conditions (Benito et al., 2003).

Yileimu Lake is surrounded by hills of granitic rocks on the west and east (Figure 1B). The 11 August $1931 M_{s} 8.0$ Fuyun earthquake caused extensive landslides, providing a large amount of siliciclastic-enriched clastic materials in the lake catchment, and thereby producing the Si-enriched mass-wasting deposits at the top of the Y20B core (Figure 2C). The other 5 horizons of mass-wasting deposits have even higher Si content than those at the top of the Y20B core (Figures 2D-H, 3), potentially implying more serious landslides caused by prehistoric great earthquakes. $\mathrm{Mn}$ content is generally low in the mass-wasting deposits (Figures 2C-H, 3), indicating oxygen-depleted sedimentary environments and rapid accumulation for these post-seismic deposits (Wils et al., 2021). TIC content is generally low and exhibits an increasing trend throughout the Y20B core, and there are no systematic correlations between the $\mathrm{Ca}$ and TIC contents (Figure 3). Therefore, a large amount of $\mathrm{Ca}$ (as well as $\mathrm{Sr}$ ) should originate from plagioclase in addition to carbonates (Figure 5A). $\mathrm{Rb} / \mathrm{Sr}$ ratio is generally low in the mass-wasting deposits (Figure 3), reflecting weak chemical weathering in the lake catchment (Fan et al., 2021). These data indicate that sediment sources for mass-wasting deposition in Yileimu Lake should have mainly been provided by earthquake-related landslides of weakly weathered granitic rocks. Overall, the mass-wasting deposits overlying the SSDS in the Y20B core reflect 6 past earthquakes (E1, E3, E7, E10, E15 and E19 in Figure 7).

Lacustrine turbidites are characterized by gradually upward decreasing grain size, and can be produced by earthquakeinduced slope failures and/or slumps in tectonically active regions (e.g., Bertrand et al., 2008; Howarth et al., 2021; Moernaut et al., 2014). However, turbidites can also be formed 


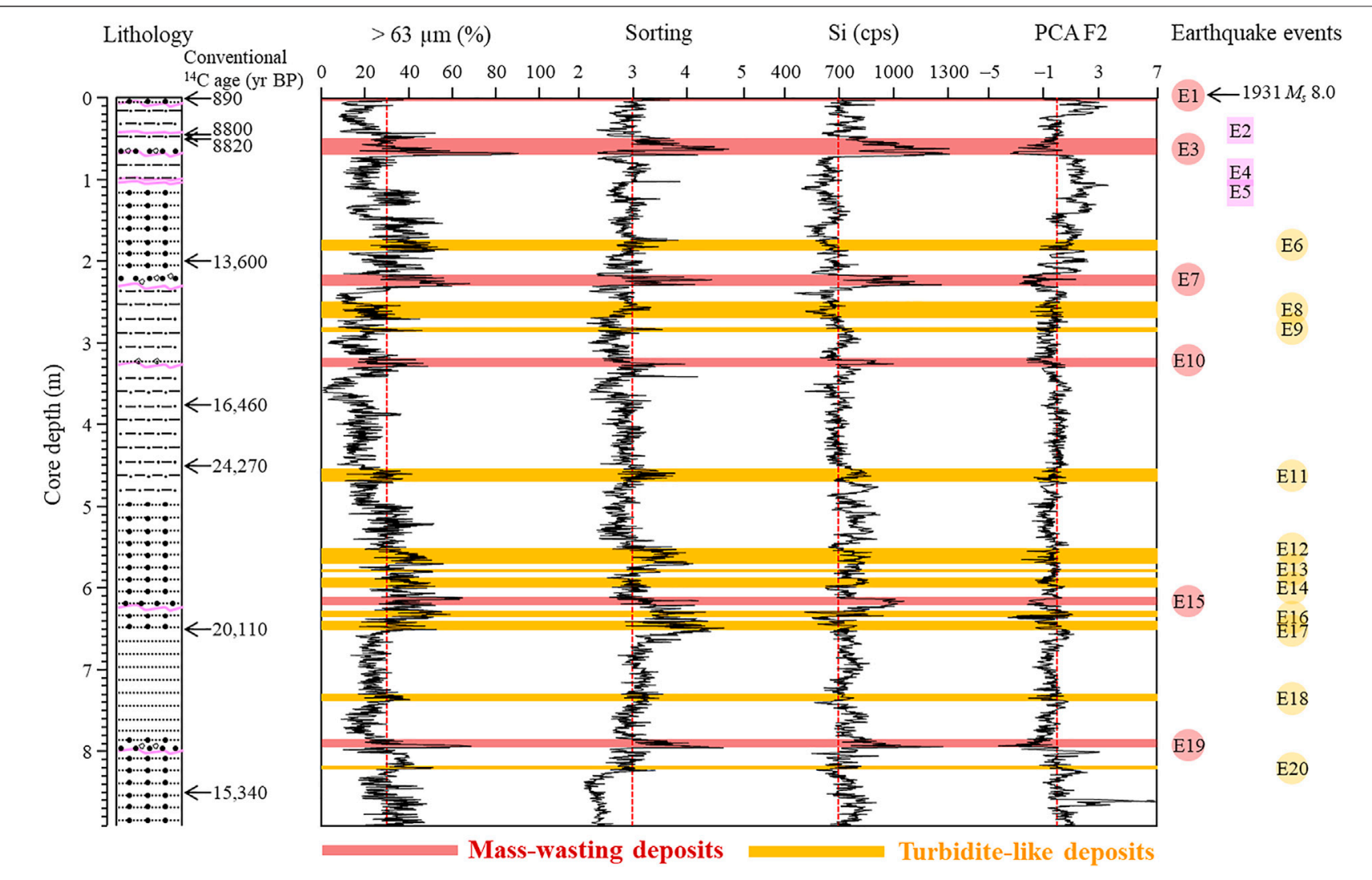

FIGURE 7| Sedimentary record of past earthquakes inferred from the mass-wasting deposits with underlying SSDS (E1, E3, E7, E10, E15 and E19), isolated SSDS (E2, E4 and E5) and turbidite-like seismites (E6, E8-E9, E11-E14, E16-E18 and E20) from the Y20B core. Lithological legends and conventional ${ }^{14} \mathrm{C}$ ages are same as Figure 2.

by flood events (Beck, 2009; Migeon et al., 2017; Praet et al., 2020). Earthquake-related turbidites were commonly characterized by rapidly accumulated and poorly sorted deposits, while floodinduced turbidites were usually well sorted and contain crossbedding structures and normally graded bedding sequences (Migeon et al., 2017; Moernaut et al., 2014) (e.g., Figure 2K). In this study, the deposits having similar grain-size structures to those turbidites are regarded as "turbidite-like" deposits. It is noted that earthquake-induced mass-wasting deposits have sorting indices $>3$, Si contents $>700 \mathrm{cps}$ and PCA F2 $<0$ that can be distinguished from flood-like deposits (sorting indices $<3$, Si contents $<700 \mathrm{cps}$ and PCA F2 $>0$ ) in Yileimu Lake (Figures 3-5). Therefore, turbidite-like deposits with sorting indices $>3$, $\mathrm{Si}$ contents $>700$ cps and PCA F2 $<0$ are interpreted as seismites in Yileimu Lake (Figure 7). When compared with the mass-wasting deposits, the turbidite-like seismites have relatively lower $\mathrm{Si}$ contents (Figures 3, 4), implying that the main sediment sources for these turbidite-like seismites were unlikely to be the Si-enriched clastic materials from extensive landslides of granitic rocks in the lake catchment. These turbidite-like seismites may have mainly been related to the re-deposition of nearshore sediments after intense shaking of the lake. Seismic shaking could cause an oscillatory movement of the water column (a seiche effect), and disturb the surface sediments at water- sediment interface (Migeon et al., 2017), resulting in successive re-deposition of sand, silt and clay, forming the turbidite-like deposits. Subaquatic slumps or slope failures within the lake should be secondary factors, because the lake floor is not very steep (Figure 1B) (e.g., Schnellmann et al., 2002). The turbiditelike seismites in the Y20B core indicate 11 potential earthquakes (E6, E8-E9, E11-E14, E16-E18 and E20 in Figure 7).

\section{Potential Magnitudes for Paleoearthquakes}

The 11 August $1931 M_{s} 8.0$ Fuyun earthquake caused extensive landslides of granitic rocks and triggered mass-wasting deposits in the Yileimu Lake catchment (Fan et al., 2020b). Seismic intensity calculation results based on intensity prediction equations (IPEs) from Wang et al. (2000) and Dowrick and Rhoades (2005) were consistent with the published seismic intensity map of the 11 August $1931 M_{s} 8.0$ Fuyun earthquake based on field survey by Shi et al. (2010). These data indicated that an intensity of 8.6 MMI (epicentral distance $50 \mathrm{~km}$ ) was required for past earthquakes to trigger extensive landslides in the Yileimu Lake catchment (Fan et al., 2020b) (Figures 8A,B). Similarly, a minimum intensity of 9 MMI was required for earthquakes produced by the Alpine Fault to cause extensive landslides in the Ellery Lake catchment (Howarth et al., 2016). The small difference of intensity thresholds for landslides in the above two 

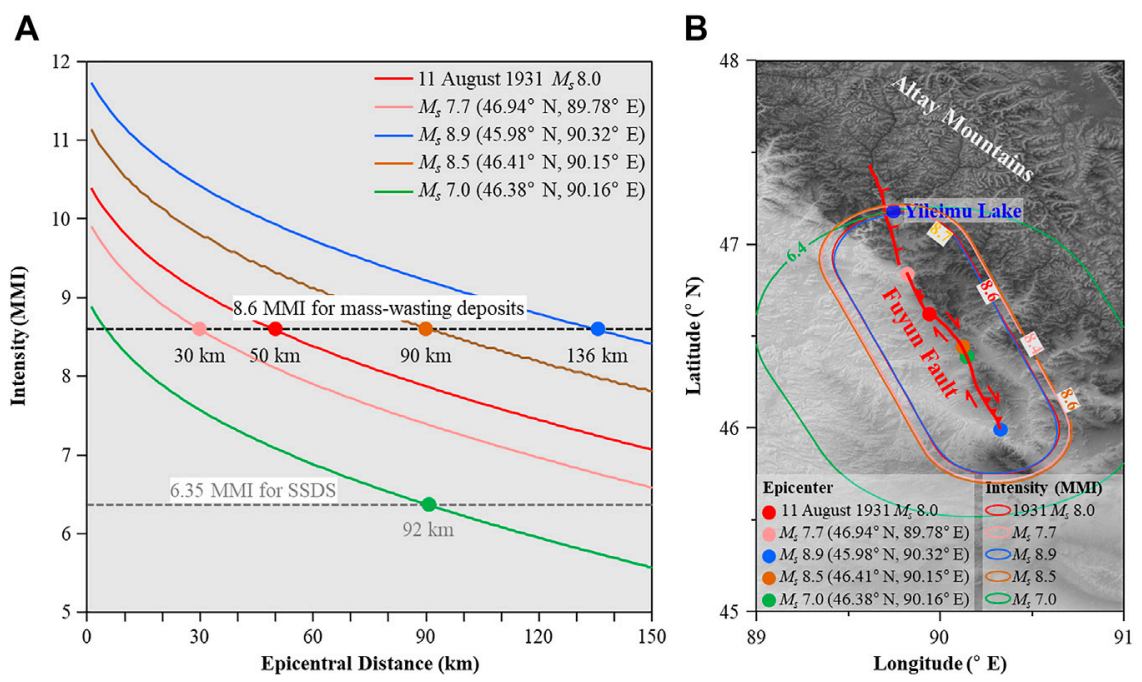

FIGURE 8 | (A) Shaking intensity variations with epicentral distance and (B) calibrated isoseismal modelling results for different magnitudes of earthquakes from different sites along the Fuyun Fault. The pink, red, brown, blue and green circles in (A,B) are in one-to-one correspondence. The intensity prediction equations (IPEs) used in (A,B) are from Wang et al. (2000), and Dowrick and Rhoades (2005), respectively. MMl, Modified Mercalli Intensity.

lake catchments may be related to the different slope angles and rock types. A local intensity of 8.6 MMI in Yileimu Lake could be produced by distant large earthquakes or proximal small earthquakes, making it difficult to determine the magnitudes of prehistoric earthquakes.

The Fuyun Fault is the main seismogenic fault in the study area. It generally consists of a $\sim 50 \mathrm{~km}$-long normal fault segment in the north and a $\sim 120 \mathrm{~km}$-long thrust-slip fault segment in the south (Figures 1A, 8B) (Klinger et al., 2011; Xu et al., 2012). All historical $M_{s} \geq 7.0$ earthquakes in the study area occurred in the thrust-slip segment (Figure 1A). Therefore, it is the southern segment of the Fuyun Fault that seems to have the great potential to trigger large earthquakes. Based on the IPEs from Wang et al. (2000) and Dowrick and Rhoades (2005), an intensity of 8.6 MMI in Yileimu Lake could be generated by an $M_{s}$ 7.7/8.9 earthquake at the north/south end of the southern fault segment (epicentral distance $30 / 136 \mathrm{~km}$ ) in the geological past (Figures $\mathbf{8 A , B}$ ), assuming these earthquakes had similar hypocentral depth, strike, dip and rake to those of the 11 August $1931 M_{s} 8.0$ Fuyun earthquake (Fan et al., 2020b). In addition, characteristic dextral offsets of terraces and stream channels produced by prehistoric $M_{s} \geq 8.0$ earthquakes from the Fuyun Fault are mainly distributed in the central part of the southern fault segment (Klinger et al., 2011). Hence, it is likely that great earthquakes occurred mainly in the central part of the southern segment of the Fuyun Fault (epicentral distance $\sim 90 \mathrm{~km}$ ). Therefore, an intensity of 8.6 MMI in Yileimu Lake should be produced by prehistoric $M_{s} \geq 8.0$ (perhaps $M_{s} 8.5$ ) earthquakes from the Fuyun Fault (Figures 6B, 8A,B).

Previous studies suggested that an intensity of 6.5 MMI was required for past earthquakes to produce in situ SSDS of linear waves in the Dead Sea, according to the computational fluid dynamics modelling results (Lu et al., 2020). However, these modelling results cannot be simply applied to Yileimu Lake because the lithology, sediment compaction and SSDS in the Y20B core, and the water depth of Yileimu Lake are significantly different from those in Dead Sea. In northern Xinjiang, a minimum intensity of $6.35 \mathrm{MMI}$ could trigger slight SSDS (e.g., linear waves), and an intensity of 7 MMI was able to cause extensive soil liquefaction ( $\mathrm{Li}$ et al., 2012). Therefore, a local intensity of 6.35 MMI was used as a threshold to trigger SSDS of linear waves in Yileimu Lake. An intensity of 6.35 MMI in Yileimu Lake was likely induced by an $M_{s} \geq 7.0$ earthquake from the central part of the southern segment of the Fuyun Fault (epicentral distance $92 \mathrm{~km}$ ) (Figures $\mathbf{8 A}, \mathbf{B}$ ). There was no evidence for historical $M_{s}<7.0$ earthquakes being able to produce SSDS in the Yileimu Lake catchment (Fan et al., 2020b). In addition, the SSDS of micro-faults (Figure 2D), convolute structures (Figure 2G) and linear waves and clastic dykes (Figure $\mathbf{2 H}$ ) underlying the mass-wasting deposits in Yileimu Lake, indicates that an intensity of 8.6 MMI (potential $M_{s} \geq 8.0$ earthquakes) was sufficient to trigger these SSDS. Therefore, the isolated SSDS of linear waves (Figures 2I,J) and a clastic dyke (Figure 2J) should indicate prehistoric $7.0 \leq M_{s}<$ 8.0 earthquakes (Figure 6B).

Turbidite seismites were triggered by a minimum shaking intensity of 5.3-5.7 MMI in Rara Lake in the central Himalaya (Ghazoui et al., 2019). In southern Altay, a historical $M_{s} 5.8$ earthquake (epicentral distance $30 \mathrm{~km}$ ) induced turbidite-like seismites in Yileimu Lake which indicated an intensity threshold of 5.51 MMI (Fan et al., 2020b). In contrast, there was no evidence that historical $M_{s}<5.5$ earthquakes could trigger turbidite-like seismites in Yileimu Lake (Fan et al., 2020b). Therefore, a minimum magnitude $M_{s} 5.5$ earthquake within a maximum distance of $25 \mathrm{~km}$ from Yileimu Lake appears to be required to cause turbidite-like seismites in the lake (Figure 6B), based on the IPEs from Wang et al. (2000) and Dowrick and Rhoades (2005). In addition, previous studies suggested a linear 
correlation between shaking intensity and turbidite thickness in the south central Chilean lakes (Moernaut et al., 2014). However, distinct lake morphologies and sediment lithology may cause different sedimentary responses to past earthquakes, producing unique intensity thresholds for various turbidites in specific lakes (Moernaut et al., 2014; Lu et al., 2021a). The lack of temporal correlation between historical earthquakes and turbidite-like seismites in Yileimu Lake makes it very difficult to assess the potential magnitudes of prehistoric earthquakes. Since there were no SSDS associated with these turbidite-like seismites, a magnitude $M_{s}<7.0$ was tentatively considered as the maximum threshold.

\section{Timing and Recurrence Behavior of Paleoearthquakes}

The ${ }^{14} \mathrm{C}$ age of organic matter from the top of the $\mathrm{Y} 20 \mathrm{~B}$ core is much older than the sampling date (Figure 2B; Table 1), possibly reflecting reservoir effects (e.g., Zhou et al., 2009). However, this ${ }^{14} \mathrm{C}$ age is not suitable for calibrating the reservoir effects of the Y20B core, because human- activities (for example, reservoir construction in Yileimu Lake, mine exploitation in Koktokay about $7 \mathrm{~km}$ east of Yileimu Lake, and agricultural activities such as grazing in the lacustrine plains) in recent decades (Fuyun County Local Chronicles Compilation Committee, 2003) should have significantly changed the reservoir effects in the shallow water regions of Yileimu Lake. The linearly fitted age-depth curve of the Y20B core shows an intercept of 8,052.1 year (Supplementary Figure S4), indicating a potential reservoir effect of thousands of years for the Y20B core. Great earthquake events such as $M_{s} \geq 8.0$ earthquakes could cause significant changes in the sediments of the whole lake (e.g., Howarth et al., 2014; Wils et al., 2021), allowing for stratigraphic correlations between event layers in the Y20A and Y20B cores (Supplementary Figure S3). The branch at $198 \mathrm{~cm}$ depth within the $\mathrm{Y} 20 \mathrm{~A}$ core has a ${ }^{14} \mathrm{C}$ age of $3,090 \pm 35$ years $\mathrm{BP}$ (Supplementary Figures S2, S3; Table 1). The ${ }^{14} \mathrm{C}$ age of organic matter at $50 \mathrm{~cm}$ depth within the Y20B core is 8,820 \pm 30 years BP (Supplementary Figures S2, S3; Table 1). The depth of $198 \mathrm{~cm}$ within the Y20A core corresponds to the depth of $50 \mathrm{~cm}$ within the Y20B core (Supplementary Figure S3), therefore, the age difference between these two corresponding depths (5,730 years) is used as the reservoir correction factor (Table 1).

In addition, the linearly fitted age-depth curve of the Y20B core also shows an anomalously old ${ }^{14} \mathrm{C}$ age at $450 \mathrm{~cm}$ depth and an anomalously young ${ }^{14} \mathrm{C}$ age at $850 \mathrm{~cm}$ depth within the $\mathrm{Y} 20 \mathrm{~B}$ (Supplementary Figure S4; Table 1). The sediments at $450 \mathrm{~cm}$ depth within the Y20B core were deposited immediately after the earthquake event E11 (Figure 7) which may have produced excessive input of old carbon into the lake through remobilization of buried soils in the lake catchment. In addition, the organic matter at $850 \mathrm{~cm}$ depth within the $\mathrm{Y} 20 \mathrm{~B}$ core was very low, and the anomalously young ${ }^{14} \mathrm{C}$ age of organic matter at $850 \mathrm{~cm}$ depth within the Y20B core may have been caused by the incorporation of young carbon into the sediments, potentially sourced from near-surface groundwater. Therefore, the ${ }^{14} \mathrm{C}$ ages obtained from 450 to $850 \mathrm{~cm}$ depths within the Y20B core are not used. Hence, a total of 7 age data points, including the sampling date of $-70 \mathrm{cal}$ year BP at the core top, the ${ }^{14} \mathrm{C}$ ages of the branch and wood at 198 and $264 \mathrm{~cm}$ depths within the Y20A core (corresponding to 50 and $72 \mathrm{~cm}$ depths within the Y20B core), and the ${ }^{14} \mathrm{C}$ ages of organic matter at $45,200,375$ and $650 \mathrm{~cm}$ depths within the Y20B core, are used in the Bayesian age-depth model. The four ${ }^{14} \mathrm{C}$ ages of organic matter are corrected through subtracting the reservoir correction factor, and then calibrated to the calendar ages (Figure 9A; Table 1).

The SSDS, mass-wasting deposits and turbidite-like seismites within the Y20B core record a total of 20 potential paleoearthquakes (E1-E20) originating from the Fuyun Fault (Figure 7). Post-seismic sediments are rapidly deposited (e.g., Howarth et al., 2014; Avşar et al., 2016; Wils et al., 2021), as evidenced by the almost same ages within the seismites (Fan et al., 2020b). Therefore, the thickness of the mass-wasting deposits and turbidite-like seismites are removed to normalize the depth of the Y20B core. In contrast, the flood-like deposits and the turbidite-like non-seismites are relatively thin and occur frequently; these sediments are not excluded in the age-depth model (Avşar et al., 2015). The Bayesian age-depth model based on the normalized core depth and 7 age data points shows an almost linear curve, indicating that there were no significant discontinuities in the Y20B core, consistent with the lithological characteristics (Figures 2A,B). The age-depth model indicates a ${ }^{14} \mathrm{C}$ age of $18.8 \mathrm{cal}$ year $\mathrm{BP}$ at $2-0.5 \mathrm{~cm}$ depths of the $\mathrm{Y} 20 \mathrm{~B}$ core, corresponding to the $1931 M_{s} 8.0$ Fuyun earthquake (Figures 2, 6, 9A,B). The Y20B core covers the past $28 \mathrm{kyr}$ (Figures 9A,B). The sedimentation rate in the last $3 \mathrm{kyr}(\sim 0.15 \mathrm{~mm} /$ year $)$ is slightly lower than the preceding period $(\sim 0.34 \mathrm{~mm} /$ year $)$.

The sedimentary proxies, except for the TIC content, of the Y20B core spanning the past $28 \mathrm{kyr}$ did not exhibit the typical climate fluctuations during the Last Glacial Maximum (LGM)-Deglaciation-Holocene periods (Figure 3). The catchment of Yileimu Lake is surrounded by high mountains to the northeast which are covered with perennial snow and ice 3,000 $\mathrm{m}$ above sea level (a.s.l.). Therefore, possible snow and ice melting during warming seasons in the geological past may have increased the transport of coarse particles into the lake, concealing the climate characteristics (cold and wet in the LGM and Deglaciation, and warm and dry in the Holocene) of the Westerlies-dominated arid Asia (e.g., Sun et al., 2013), including the Altay region, and reducing the difference in the percentages of $>63 \mu \mathrm{m}$ fraction between the seismic horizon of the E15 event and the adjacent non-seismic horizons (Figure 7). The TIC in the Y20B core was mainly from carbonates produced by inorganic precipitation within the lake water, because there were no carbonate rocks in the Yileimu Lake catchment. The TIC contents cannot be ignored throughout the Y20B core (Figure 3), implying a dominant subaquatic environment. The Bayesian age-depth model of the Y20A core indicates that the sedimentation rates in the nearshore zone of Yileimu Lake were much lower than those in the depocenter (Supplementary Figures S2, S3). This was probably because the depocenter of Yileimu Lake was closer to the rivers entering the lake (Figure 1B).

The 6 potential $M_{s} \geq 8.0$ earthquakes indicated by the masswasting deposits overlying SSDS in the Y20B core occurred 15-22, $3,132-3,535, \quad 7,824-9,396, \quad 10,084-11,910, \quad 17,425-20,868$ and $22,307-26,665$ cal year BP, respectively, based on the Bayesian 


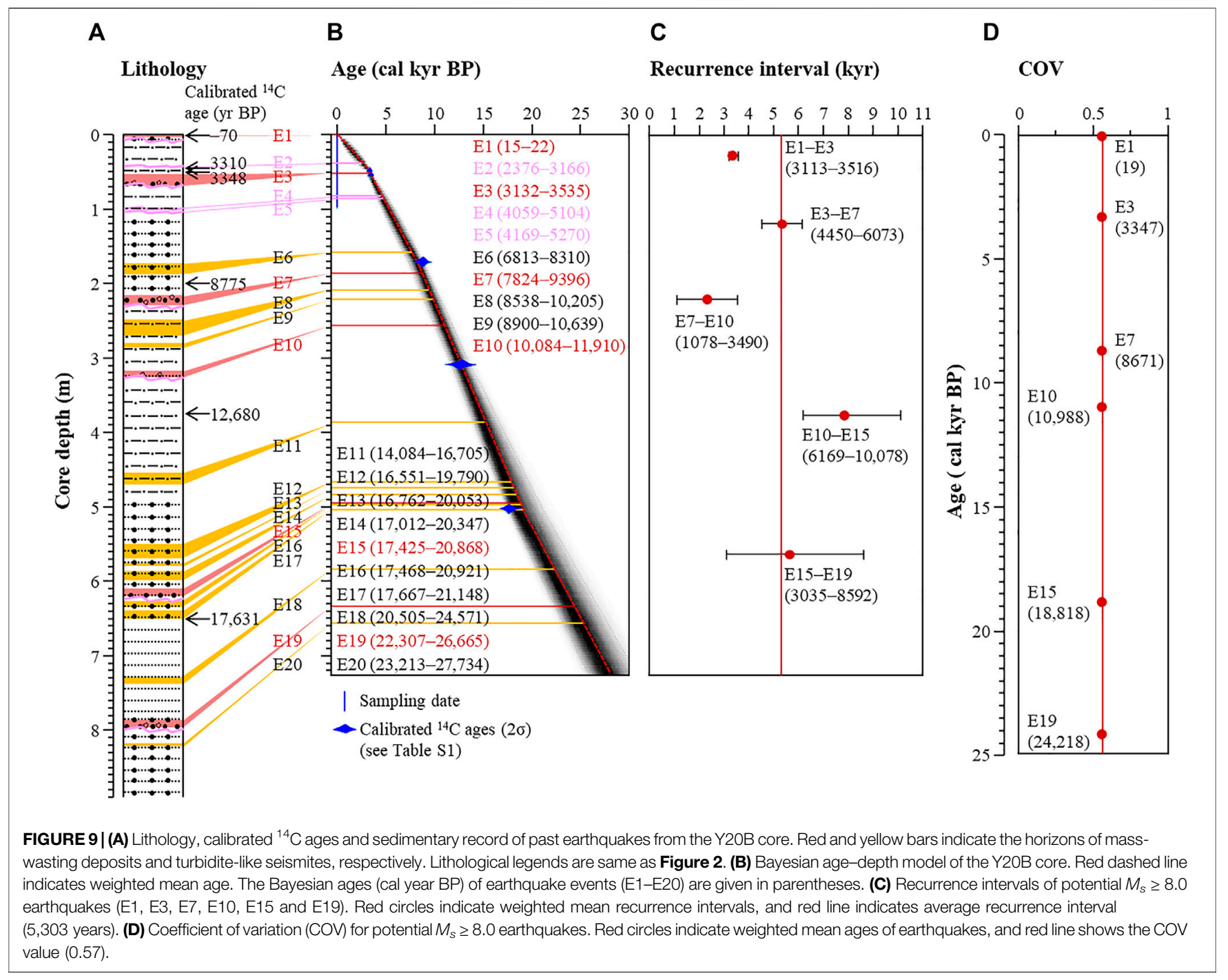

age-depth model (Figure 9B). The recurrence intervals for these earthquakes were between 2,317 and 7,830 years with an average of 5,303 years (Figure 9C), much longer than the dating uncertainties (Figures 9B,C), and much shorter than the previously published recurrence interval of 9,700 $\pm 3,300$ years for prehistoric $M_{s} \geq 8.0$ earthquakes originating from the Fuyun Fault (Xu et al., 2012). The timing of these earthquakes was weakly periodic, with a coefficient of variation (COV) of 0.57 (Figure 9D) (Moernaut, 2020). The three potential $M_{s} \geq 7.0$ earthquakes reflected by the three isolated SSDS in the Y20B core occurred 2,376-3,166, 4,059-5,104 and 4,169-5,270 cal year BP, respectively (Figure 9B). The minimum recurrence interval of these earthquakes was 110 years, comparable to the previously published interval of 96 years (Fan et al., 2020b). The 11 potential $M_{s} \geq 5.5$ earthquakes implied by the turbidite-like seismites in the Y20B core occurred between 6,813 and 8,310 and 23,213-27,734 cal year BP, and mainly occurred before 14,084-16,705 cal year BP (Figure 9B).

Low sedimentation rate may hinder the identification of sediment features produced by earthquakes with relatively short recurrence intervals (Moernaut et al., 2014). However, a much higher frequency of potential $M_{s} \geq 7.0$ earthquakes were recorded by the SSDS in the Y20B core over the last $5 \mathrm{kyr}$, during which time the sedimentation rate of the Y20B core was even lower than the preceding period (Figure 9B). Future studies on multi-lake paleoseismic records from different parts of the Fuyun Fault may reveal an even more accurate recurrence pattern of past earthquakes, since small, distant earthquakes (e.g., $M_{s} \geq 5.5$ ) may not be recorded in a single lake, and individual lakes with different morphologies, lake levels, sedimentation rates, sediment sources and catchment reliefs may also have different sensitivities to past earthquakes (Moernaut et al., 2014; Hubert-Ferrari et al., 2020; Lu et al., 2021b).

\section{CONCLUSION}

Lake sediments in tectonically active regions can provide a complementary paleoseismic record. Widely distributed subaquatic faults in Yileimu Lake, imaged by reflection seismic profiles, indicate that the lake was very sensitive to 
past earthquakes originating from the Fuyun Fault. The mass-wasting deposits overlying SSDS in an 890-cm long sediment core from Yileimu Lake reveals six paleoearthquakes with potential magnitudes of $M_{s} \geq 8.0$, and isolated SSDS reflect three additional potential $M_{s} \geq$ 7.0 paleoearthquakes. Potentially seismic turbidite-like deposits can be distinguished from those with non-seismic origins by sorting indices $>3$ and $\mathrm{Si}$ contents $>700 \mathrm{cps}$. The turbidite-like seismites record 11 potential $M_{s} \geq 5.5$ paleoearthquakes. Radiocarbon dating and stratigraphic correlations constrain the timing of these past earthquakes to $\sim 28 \mathrm{cal} \mathrm{kyr} \mathrm{BP.} \mathrm{This} \mathrm{paleoseismic} \mathrm{record} \mathrm{suggests} \mathrm{a} \mathrm{weakly}$ periodic pattern with recurrence intervals between 2,317 and 7,830 years and an average of 5,303 years for potential $M_{s} \geq$ 8.0 earthquakes, and reveals an unprecedented high frequency of potential $M_{s} \geq 7.0$ earthquakes originating from the Fuyun Fault in the last $5 \mathrm{kyr}$. These data provide new insights into the recurrence behavior of large earthquakes from intraplate, slow-slipping faults, and highlight the urgent need for an improved assessment of seismic hazards and risks in the Fuyun Fault zone. Future studies on lake sediments with higher sedimentation rates and with wider spatial coverage may help to obtain a more complete paleoseismic record.

\section{DATA AVAILABILITY STATEMENT}

The raw data supporting the conclusions of this article will be made available by the authors, without undue reservation.

\section{REFERENCES}

Avşar, U., Hubert-Ferrari, A., Batist, M. D., and Fagel, N. (2014). A 3400 Year Lacustrine Paleoseismic Record from the North Anatolian Fault, Turkey: Implications for Bimodal Recurrence Behavior. Geophys. Res. Lett. 41, 377-384. doi:10.1002/2013GL058221

Avşar, U., Hubert-Ferrari, A., De Batist, M., Schmidt, S., and Fagel, N. (2015). Sedimentary Records of Past Earthquakes in Boraboy Lake during the Last Ca 600 Years (North Anatolian Fault, Turkey). Palaeogeogr. Palaeoclimatol. Palaeoecol. 433, 1-9. doi:10.1016/j.palaeo.2015.04.031

Avşar, U., Jónsson, S., Avşar, Ö., and Schmidt, S. (2016). Earthquake-induced SoftSediment Deformations and Seismically Amplified Erosion Rates Recorded in Varved Sediments of Köyceğiz Lake (SW Turkey). J. Geophys. Res. Solid Earth 121, 4767-4779. doi:10.1002/2016JB012820

Bai, M. X., Luo, F. Z., Yin, G. H., Xiang, Z. Y., Sheng, J., Shi, S. Z., et al. (1996). Kokotokay-Ertai Active Fault Zone in Xinjiang. Inl. Earthq. 10, 319-328. (in Chinese with English abstract). doi:10.16256/j.issn.1001-8956.1996. 04.005

Beck, C. (2009). "Late Quaternary Lacustrine Paleo-Seismic Archives in northwestern Alps: Examples of Earthquake-Origin Assessment of Sedimentary Disturbances". Earth-Science Rev. 96, 327-344. doi:10.1016/j.earscirev.2009. 07.005

Benito, G., Sánchez-Moya, Y., and Sopeña, A. (2003). Sedimentology of High-Stage Flood Deposits of the Tagus River, Central Spain. Sediment. Geology. 157, 107-132. doi:10.1016/S0037-0738(02)00196-3

Berryman, K. R., Cochran, U. A., Clark, K. J., Biasi, G. P., Langridge, R. M., and Villamor, P. (2012). Major Earthquakes Occur Regularly on an Isolated Plate Boundary Fault. Science 336, 1690-1693. doi:10.1126/science.1218959

\section{AUTHOR CONTRIBUTIONS}

JF: Conceptualization, data curation, formal analysis, investigation, writing-original draft, writing-review and editing, project administration, resources, supervision. HX: Data curation, investigation, writing-review and editing. WS: data curation, investigation. QG: Data curation, investigation. SZ: Investigation. XW: Data curation. MC: Data curation. SH: Investigation. JW: Data curation. JX: Conceptualization, writing - review and editing.

\section{FUNDING}

This study is supported by the National Nonprofit Fundamental Research Grant of China, Institute of Geology, China Earthquake Administration (IGCEA2009).

\section{ACKNOWLEDGMENTS}

The authors are grateful to Yin Lu from the Institute of Geology, University of Innsbruck (Innsbruck, Austria) for insightful discussions.

\section{SUPPLEMENTARY MATERIAL}

The Supplementary Material for this article can be found online at: https:/www.frontiersin.org/articles/10.3389/feart.2022.828801/ full\#supplementary-material

Bertrand, S., Charlet, F., Chapron, E., Fagel, N., and De Batist, M. (2008). Reconstruction of the Holocene Seismotectonic Activity of the Southern Andes from Seismites Recorded in Lago Icalma, Chile, 39 ${ }^{\circ} \mathrm{S}$. Palaeogeogr. Palaeoclimatol. Palaeoecol. 259, 301-322. doi:10.1016/j.palaeo.2007.10.013

Blaauw, M., and Christen, J. A. (2011). Flexible Paleoclimate Age-Depth Models Using an Autoregressive Gamma Process. Bayesian Anal. 6, 457-474. doi:10. 1214/ba/1339616472

Blott, S. J., and Pye, K. (2001). GRADISTAT: a Grain Size Distribution and Statistics Package for the Analysis of Unconsolidated Sediments. Earth Surf. Process. Landforms 26, 1237-1248. doi:10.1002/esp.261

Brock, F., Higham, T., Ditchfield, P., and Ramsey, C. B. (2010). Current Pretreatment Methods for AMS Radiocarbon Dating at the Oxford Radiocarbon Accelerator Unit (Orau). Radiocarbon 52, 103-112. doi:10. $1017 /$ S0033822200045069

Chen, J., van Loon, A. J., Han, Z., and Chough, S. K. (2009). Funnel-shaped, Breccia-Filled Clastic Dykes in the Late Cambrian Chaomidian Formation (Shandong Province, China). Sediment. Geology. 221, 1-6. doi:10.1016/j.sedgeo. 2009.09.006

Cui, P., Lin, Y.-m., and Chen, C. (2012). Destruction of Vegetation Due to GeoHazards and its Environmental Impacts in the Wenchuan Earthquake Areas. Ecol. Eng. 44, 61-69. doi:10.1016/j.ecoleng.2012.03.012

Ding, G. Y. (1985). The Fuyun Earthquake Fault Zone. Beijing: Seismological Press. (in Chinese).

Dowrick, D. J., and Rhoades, D. A. (2005). Revised Models for Attenuation of Modified Mercalli Intensity in New Zealand Earthquakes. Bnzsee 38, 185-214. doi:10.5459/bnzsee.38.4.185-214

Fan, J., Jiang, H., Shi, W., Guo, Q., Zhang, S., Wei, X., et al. (2021). A 450-year Warming and Wetting Climate in Southern Altay Inferred from a Yileimu Lake Sediment Core. Quat. Int. 592, 37-50. doi:10.1016/j.quaint.2021.04.035 
Fan, J., Jiang, H., Shi, W., Guo, Q., Zhang, S., Wei, X., et al. (2020b). A 450-year Lacustrine Record of Recurrent Seismic Activities Around the Fuyun Fault, Altay Mountains, Northwest China. Quat. Int. 558, 75-88. doi:10.1016/j.quaint. 2020.08 .051

Fan, J., Wei, X., Shi, W., Guo, Q., Zhang, S., Xu, H., et al. (2020a). Response of Tree Rings to Earthquakes during the Past 350 Years at Jiuzhaigou in the Eastern Tibet. Sci. Total Environ. 731, 138714. doi:10.1016/j.scitotenv.2020.138714

Fan, J., Xiao, J., and Qin, X. (2019). Millennial- and Centennial-Scale Droughts at the Northern Margin of the East Asian Summer Monsoon during the Last Deglaciation: Sedimentological Evidence from Dali Lake. Palaeogeogr. Palaeoclimatol. Palaeoecol. 514, 361-372. doi:10.1016/j.palaeo.2018.11.001

Fan, J., Xiao, J., Wen, R., Zhang, S., Wang, X., Cui, L., et al. (2016). Droughts in the East Asian Summer Monsoon Margin during the Last 6 Kyrs: Link to the North Atlantic Cooling Events. Quat. Sci. Rev. 151, 88-99. doi:10.1016/j.quascirev. 2016.09.001

Fuyun County Local Chronicles Compilation Committee (2003). Annals of Fuyun County. Urumqi: Volksverlag Xinjiang. (in Chinese).

Ghazoui, Z., Bertrand, S., Vanneste, K., Yokoyama, Y., Nomade, J., Gajurel, A. P., et al. (2019). Potentially Large post-1505 AD Earthquakes in Western Nepal Revealed by a lake Sediment Record. Nat. Commun. 10, 2258. doi:10.1038/ s41467-019-10093-4

Howarth, J. D., Fitzsimons, S. J., Norris, R. J., and Jacobsen, G. E. (2012). Lake Sediments Record Cycles of Sediment Flux Driven by Large Earthquakes on the Alpine Fault, New Zealand. Geology 40, 1091-1094. doi:10.1130/G33486.1

Howarth, J. D., Fitzsimons, S. J., Norris, R. J., and Jacobsen, G. E. (2014). Lake Sediments Record High Intensity Shaking that Provides Insight into the Location and Rupture Length of Large Earthquakes on the Alpine Fault, New Zealand. Earth Planet. Sci. Lett. 403, 340-351. doi:10.1016/j.epsl.2014. 07.008

Howarth, J. D., Fitzsimons, S. J., Norris, R. J., Langridge, R., and Vandergoes, M. J. (2016). A 2000 Yr Rupture History for the Alpine Fault Derived from Lake Ellery, South Island, New Zealand. Geol. Soc. America Bull. 128, 627-643. doi:10.1130/B31300.1

Howarth, J. D., Orpin, A. R., Kaneko, Y., Strachan, L. J., Nodder, S. D., Mountjoy, J. J., et al. (2021). Calibrating the marine Turbidite Palaeoseismometer Using the 2016 Kaikōura Earthquake. Nat. Geosci. 14, 161-167. doi:10.1038/s41561021-00692-6

Hubert-Ferrari, A., Lamair, L., Hage, S., Schmidt, S., Çağatay, M. N., and Avşar, U. (2020). A 3800 Yr Paleoseismic Record (Lake Hazar Sediments, Eastern Turkey): Implications for the East Anatolian Fault Seismic Cycle. Earth Planet. Sci. Lett. 538, 116152. doi:10.1016/j.epsl.2020.116152

Jiang, H., Zhong, N., Li, Y., Ma, X., Xu, H., Shi, W., et al. (2017). A Continuous 13.3ka Record of Seismogenic Dust Events in Lacustrine Sediments in the Eastern Tibetan Plateau. Sci. Rep. 7, 15686. doi:10.1038/s41598-017-16027-8

Jiang, H., Zhong, N., Li, Y., Xu, H., Yang, H., and Peng, X. (2016). Soft Sediment Deformation Structures in the Lixian Lacustrine Sediments, Eastern Tibetan Plateau and Implications for Postglacial Seismic Activity. Sediment. Geology. 344, 123-134. doi:10.1016/j.sedgeo.2016.06.011

Klinger, Y., Etchebes, M., Tapponnier, P., and Narteau, C. (2011). Characteristic Slip for Five Great Earthquakes along the Fuyun Fault in China. Nat. Geosci 4, 389-392. doi:10.1038/NGEO1158

Kremer, K., Gassner-Stamm, G., Grolimund, R., Wirth, S. B., Strasser, M., and Fäh, D. (2020). A Database of Potential Paleoseismic Evidence in Switzerland. J. Seismol. 24, 247-262. doi:10.1007/s10950-020-09908-5

Li, Z. Y., Cao, Z. Z., and Li, Y. R. (2012). New Prediction Formula of Sand Liquefied on Bachu-Jiashi Earthquake Survey. Amm 170-173, 2880-2884. doi:10.4028/ www.scientific.net/AMM.170-173.2880

Lin, A., and Lin, S. j. (1998). Tree Damage and Surface Displacement: The 1931 M 8.0 Fuyun Earthquake. J. Geology. 106, 751-758. doi:10.1086/516058

Lu, Y., Moernaut, J., Bookman, R., Waldmann, N., Wetzler, N., Agnon, A., et al. (2021a). A New Approach to Constrain the Seismic Origin for Prehistoric Turbidites as Applied to the Dead Sea Basin. Geophys. Res. Lett. 48, e2020GL090947. doi:10.1029/2020GL090947

Lu, Y., Moernaut, J., Waldmann, N., Bookman, R., Ian Alsop, G., Hubert-Ferrari, A., et al. (2021b). Orbital- and Millennial-Scale Changes in Lake-Levels Facilitate Earthquake-Triggered Mass Failures in the Dead Sea Basin. Geophys. Res. Lett. 48, e2021GL093391. doi:10.1029/2021GL093391
Lu, Y., Waldmann, N., Alsop, G. I., and Marco, S. (2017). Interpreting Soft Sediment Deformation and Mass Transport Deposits as Seismites in the Dead Sea Depocenter. J. Geophys. Res. Solid Earth 122, 8305-8325. doi:10. 1002/2017JB014342

Lu, Y., Wetzler, N., Waldmann, N., Agnon, A., Biasi, G. P., and Marco, S. (2020). A 220,000-Year-Long Continuous Large Earthquake Record on a Slow-Slipping Plate Boundary. Sci. Adv. 6, eaba4170. doi:10.1126/sciadv.aba4170

Migeon, S., Garibaldi, C., Ratzov, G., Schmidt, S., Collot, J.-Y., Zaragosi, S., et al. (2017). Earthquake-triggered Deposits in the Subduction Trench of the north Ecuador/south Colombia Margin and Their Implication for Paleoseismology. Mar. Geology. 384, 47-62. doi:10.1016/j.margeo.2016.09.008

Moernaut, J., Daele, M. V., Heirman, K., Fontijn, K., Strasser, M., Pino, M., et al. (2014). Lacustrine Turbidites as a Tool for Quantitative Earthquake Reconstruction: New Evidence for a Variable Rupture Mode in South central Chile. J. Geophys. Res. Solid Earth 119, 1607-1633. doi:10.1002/ 2013JB010738

Moernaut, J. (2020). Time-dependent Recurrence of strong Earthquake Shaking Near Plate Boundaries: A lake Sediment Perspective. Earth-Science Rev. 210, 103344. doi:10.1016/j.earscirev.2020.103344

Moernaut, J., Van Daele, M., Fontijn, K., Heirman, K., Kempf, P., Pino, M., et al. (2018). Larger Earthquakes Recur More Periodically: New Insights in the Megathrust Earthquake Cycle from Lacustrine Turbidite Records in South-central Chile. Earth Planet. Sci. Lett. 481, 9-19. doi:10.1016/j.epsl. 2017.10.016

Monecke, K., Anselmetti, F. S., Becker, A., Sturm, M., and Giardini, D. (2004). The Record of Historic Earthquakes in lake Sediments of Central Switzerland. Tectonophysics 394, 21-40. doi:10.1016/j.tecto.2004.07.053

Moretti, M. (2000). Soft-sediment Deformation Structures Interpreted as Seismites in Middle-Late Pleistocene Aeolian Deposits (Apulian Foreland, Southern Italy). Sediment. Geology. 135, 167-179. doi:10.1016/S0037-0738(00)00070-1

Oswald, P., Strasser, M., Hammerl, C., and Moernaut, J. (2021). Seismic Control of Large Prehistoric Rockslides in the Eastern Alps. Nat. Commun. 12, 1059. doi:10.1038/s41467-021-21327-9

Pollitz, F., Vergnolle, M., and Calais, E. (2003). Fault Interaction and Stress Triggering of Twentieth century Earthquakes in Mongolia. J. Geophys. Res. 108, 2503. doi:10.1029/2002JB002375

Praet, N., Van Daele, M., Collart, T., Moernaut, J., Vandekerkhove, E., Kempf, P., et al. (2020). Turbidite Stratigraphy in Proglacial Lakes: Deciphering Trigger Mechanisms Using a Statistical Approach. Sedimentology 67, 2332-2359. doi: $10.1111 /$ sed.12703

Ramsey, C. B., and Lee, S. (2013). Recent and Planned Developments of the Program OxCal. Radiocarbon 55, 720-730. doi:10.1017/S0033822200057878

Reimer, P. J., Austin, W. E. N., Bard, E., Bayliss, A., Blackwell, P. G., Bronk Ramsey, C., et al. (2020). The IntCal20 Northern Hemisphere Radiocarbon Age Calibration Curve (0-55 Cal kBP). Radiocarbon 62, 725-757. doi:10.1017/ RDC.2020.41

Schnellmann, M., Anselmetti, F. S., Giardini, D., McKenzie, J. A., and Ward, S. N. (2002). Prehistoric Earthquake History Revealed by Lacustrine Slump Deposits. Geol 30, 1131-1134. doi:10.1130/0091-7613(2002)030<1131:PEHRBL $>2.0$. $\mathrm{CO} ; 2$

Shen, J., Li, Y. Z., Wang, Y. P., and Song, F. M. (2003). The Active Faults in Altai Mountains. Earth Sci. Front. 10, 132-141. (in Chinese with English abstract). doi:10.3321/j.issn:1005-2321.2003.z1.020

Shi, J., Shen, J., Bai, M. X., and Shi, G. L. (2010). Intensity Image Revision on Fuyun 8.0 Earthquake on Aug. 11, 1931 in Xinjiang. Inland Earthq 24, 37-40. (in Chinese with English abstract). doi:10.3969/j.issn.1001-8956.2010.01.007

Sims, J. D. (1973). Earthquake-induced Structures in Sediments of Van Norman Lake, San Fernando, California. Science 182, 161-163. doi:10.1126/science.182. 4108.161

Strasser, M., Anselmetti, F. S., Fäh, D., Giardini, D., and Schnellmann, M. (2006). Magnitudes and Source Areas of Large Prehistoric Northern Alpine Earthquakes Revealed by Slope Failures in Lakes. Geol 34, 1005-1008. doi:10.1130/G22784A.1

Sullivan, K. M., and Hossain, S. M. M. (2010). Earthquake Mortality in Pakistan. Disasters 34, 176-183. doi:10.1111/j.1467-7717.2009.01121.x

Sun, A., Feng, Z., Ran, M., and Zhang, C. (2013). Pollen-recorded Bioclimatic Variations of the Last $\sim 22,600$ Years Retrieved from Achit Nuur Core in the 
Western Mongolian Plateau. Quat. Int. 311, 36-43. doi:10.1016/j.quaint.2013. 07.002

Suter, F., Martínez, J. I., and Vélez, M. I. (2011). Holocene Soft-Sediment Deformation of the Santa Fe-Sopetrán Basin, Northern Colombian Andes: Evidence for Pre-hispanic Seismic Activity? Sediment. Geology. 235, 188-199. doi:10.1016/j.sedgeo.2010.09.018

Van Daele, M., Cnudde, V., Duyck, P., Pino, M., Urrutia, R., and De Batist, M. (2014). Multidirectional, Synchronously-Triggered Seismo-Turbidites and Debrites Revealed by X-ray Computed Tomography (CT). Sedimentology 61, 861-880. doi:10.1111/sed.12070

Van Daele, M., Meyer, I., Moernaut, J., De Decker, S., Verschuren, D., and De Batist, M. (2017). A Revised Classification and Terminology for Stacked and Amalgamated Turbidites in Environments Dominated by (Hemi)pelagic Sedimentation. Sediment. Geology. 357, 72-82. doi:10.1016/j.sedgeo.2017.06.007

Vanholder, R., Sever, M. S., De Smet, M., Erek, E., and Lameire, N. (2001). Intervention of the Renal Disaster Relief Task Force in the 1999 Marmara, Turkey Earthquake. Kidney Int. 59, 783-791. doi:10.1046/j.1523-1755.2001. 059002783.X

Wang, S. Y., Yu, Y. X., Gao, A. J., and Yan, X. J. (2000). Development of Attenuation Relations for Ground Motion in China. Earthq. Res. CHN. 16, 99-106. (in Chinese with English abstract). doi:10.3969/j.issn.1001-4683.2000.02.001

Wetzler, N., Marco, S., and Heifetz, E. (2010). Quantitative Analysis of Seismogenic Shear-Induced Turbulence in lake Sediments. Geology 38, 303-306. doi:10. 1130/G30685.1

Wils, K., Daryono, M. R., Praet, N., Santoso, A. B., Dianto, A., Schmidt, S., et al. (2021). The Sediments of Lake Singkarak and Lake Maninjau in West Sumatra Reveal Their Earthquake, Volcanic and Rainfall History. Sediment. Geology. 416, 105863. doi:10.1016/j.sedgeo.2021.105863
Xu, X., and Deng, Q. (1996). Nonlinear Characteristics of Paleoseismicity in China. J. Geophys. Res. 101, 6209-6231. doi:10.1029/95JB01238

Xu, X. W., Sun, X. Z., Tan, X. B., Li, K., Yu, G. H., Etchebes, M., et al. (2012). Fuyun Fault: Long-Term Faulting Behavior under Low Crustal Strain Rate. Seismol. Geol. 34, 606-617. (in Chinese with English abstract). doi:10.3969/j.issn.02534967.2012.04.007

Zhou, A.-f., Chen, F.-h., Wang, Z.-l., Yang, M.-l., Qiang, M.-r., and Zhang, J.-w. (2009). Temporal Change of Radiocarbon Reservoir Effect in Sugan Lake, Northwest China during the Late Holocene. Radiocarbon 51, 529-535. doi:10. $1017 /$ S0033822200055909

Conflict of Interest: The authors declare that the research was conducted in the absence of any commercial or financial relationships that could be construed as a potential conflict of interest.

Publisher's Note: All claims expressed in this article are solely those of the authors and do not necessarily represent those of their affiliated organizations, or those of the publisher, the editors and the reviewers. Any product that may be evaluated in this article, or claim that may be made by its manufacturer, is not guaranteed or endorsed by the publisher.

Copyright $\odot 2022$ Fan, Xu, Shi, Guo, Zhang, Wei, Cai, Huang, Wang and Xiao. This is an open-access article distributed under the terms of the Creative Commons Attribution License (CC BY). The use, distribution or reproduction in other forums is permitted, provided the original author(s) and the copyright owner(s) are credited and that the original publication in this journal is cited, in accordance with accepted academic practice. No use, distribution or reproduction is permitted which does not comply with these terms. 